\title{
Cross-country IPOs: What explains differences in underpricing? ${ }^{\hbar}$
}

\author{
Suman Banerjee ${ }^{\mathrm{a}, *}$, Lili Dai ${ }^{\mathrm{b}}$, Keshab Shrestha ${ }^{\mathrm{c}}$ \\ a Nanyang Business School, Nanyang Technological University, Nanyang Avenue, 639798, Singapore, Singapore \\ b Erasmus School of Economics, Erasmus Research Institute of Management, Erasmus University Rotterdam, 3062 PA Rotterdam, Netherlands \\ ${ }^{c}$ Risk Management Institute, National University of Singapore, 21 Heng Mui Keng Terrace, 119613, Singapore, Singapore
}

\section{A R T I C L E I N F O}

\section{Article history:}

Received 20 October 2010

Received in revised form 1 June 2011

Accepted 6 June 2011

Available online 2 July 2011

\section{JEL classification:}

G15

G28

G32

\section{Keywords:}

IPO underpricing

Information asymmetry

Home-country bias

Law enforcement

Litigation risk

\begin{abstract}
A B S T R A C T
We study the impacts of country-level information asymmetry, investors' home-country bias, effectiveness of contract enforcement mechanisms, and accessibility of legal recourse on IPO underpricing in 36 countries around the globe. We find evidence consistent with all four of our hypotheses. First, we find a positive and significant effect of country-level information asymmetry on IPO underpricing. Second, our empirical evidence is consistent with the agency-cost-based explanation of IPO underpricing. We find that lower cost to entice the block holders, measured by domestic investors' home-country bias, reduces IPO underpricing. Third, we find that effective contract enforcement mechanisms help to reduce IPO underpricing. Finally, we find a positive relation between the accessibility of legal recourse and IPO underpricing.
\end{abstract}

(c) 2011 Elsevier B.V. All rights reserved.

\section{Introduction}

IPO underpricing has been a pervasive empirical phenomenon for decades. Studies of IPO underpricing date back as far as the early 1970s (Ibbotson (1975); Stoll and Curley (1970)), and researchers continue to observe the phenomenon not only in the U.S., but also in countries around the globe. ${ }^{1}$ The extent of underpricing varies widely from country to country as well. ${ }^{2}$ For example, Loughran et al. (1994) report that the average underpricing ranges 3\% in Malaysia. In our sample of 36 countries during the period 2000 to 2006 , we find that the average underpricing ranges from $4.33 \%$ in Norway to $57.14 \%$ in China. However, despite the wide global variation of underpricing, the IPO literature has been almost exclusively preoccupied with the determinants on IPO underpricing within a single

\footnotetext{
is We would like to thank Sugato Bhattacharyya, John Chalmers, Mark Flannery, Vladimir Gatchev, Denis Gromb, David Hirshleifer, Ravi Jagannathan, Jason Karceski, Ron Masulis, Thomas H. Noe, Lilian Ng, Jay Ritter, and Duane Seppi for helpful comments. Suman Banerjee acknowledges financial support from the Singapore Ministry of Education RCC grant.

* Corresponding author. Tel.: + 6567906237.

E-mail address: sbanerjee@ntu.edu.sg (S. Banerjee).

1 For excellent review and discussion on recent IPO underpricing literature, see Ljungqvist (2007), and Ritter and Welch (2002).

2 See Table 6 in Ritter (2003) for IPO underpricing taken from different studies. Also see Table 1 in Loughran et al. (1994) for IPO underpricing worldwide, which is routinely updated from Professor Jay Ritter's website.
} 
country rather than across international borders. ${ }^{3}$ In this paper, we present an empirical investigation on the sources of cross-country variation of IPO underpricing.

We hypothesize that the variation of IPO underpricing across countries can be explained by at least four country-level characteristics, namely country-level information asymmetry, investors' home-country bias, effectiveness of contract enforcement mechanisms, and accessibility of legal recourse. ${ }^{4}$ Our hypotheses are motivated by the observation that for any asset, including IPOs, returns directly depend on how well the financial system carries out its main functions: diversification of risk, the monitoring of incumbent management, exertion of corporate control mechanisms, and protection of stakeholders' rights. These market performances to a large extent depend on information dissemination mechanisms, investors' preference, and rules and regulations as well as accessibility and implementation of such rules and regulations.

Our study recalls lines of inquiry pursued in Henderson et al. (2006), and Kim and Weisbach (2008). Henderson et al. (2006) examine the reasons why firms rely on multiple sources of capital and the factors that affect their choices. Kim and Weisbach (2008) find evidence that globally firms do raise capital for investment purposes. Given that firms do raise substantial capital for investment around the globe, two natural questions arise: What are the costs for raising capital worldwide? And which factors affect these costs? From an IPO perspective, our paper sheds some light on these two important questions in following four hypotheses.

First, consistent with the well-documented asymmetric information theory on IPO underpricing, we argue that the differences in country-level information asymmetry influence differences in IPO underpricing; that is, a higher level of information asymmetry is associated with a higher level of IPO underpricing. ${ }^{5}$ We identify two types of information asymmetry, namely, "insider-outsider" information asymmetry and "outsider-outsider" information asymmetry, and hypothesize that both types of information asymmetry tend to increase IPO underpricing. ${ }^{6}$

Second, as Stoughton and Zechner (1998) state, IPO underpricing is one mechanism to attract block holders, who provide better monitoring and thereby, increase firm value. The issuing firm bears the cost of underpricing as a way to entice block holders. Thus, we expect that in countries where investors are favorably biased towards their domestic stocks - willing to hold proportionately more domestic equity in their portfolio - the cost to entice these investors as block holder will be relatively lower. Therefore, we expect a negative relation between investors' home-country bias and IPO underpricing.

Inefficient enforcement of contracts often leads to "corporate self-dealings" - transactions designed solely to expropriate outside shareholders' wealth by connected or influential shareholders. Problem with "self-dealing" transactions is that these transactions always benefit one group of shareholders at the expense of the others - creating a divergence in valuation and consequently, lowering the participation of "not-so connected" investors. Attracting these investors back requires that the firm either pays upfront incentives, like discounted offer price, or puts in place credible mechanisms which discourage such self-dealing transactions. Obviously, to a large extent these two mechanisms are substitutes of each other and thus, we predict a negative relation between effectiveness of contract enforcement mechanisms and IPO underpricing.

Finally, in line with Hughes and Thakor (1992) and Tinic (1988), we argue that IPO underpricing can also be considered as an ex-ante insurance premium against future litigation risk. Hence, we predict that IPO underpricing is positively related to the investors' accessibility of legal recourse and the level of penalties associated with insiders' wrongdoings.

We test our hypotheses using data from 36 countries over the period between 2000 and 2006. In line with the commonly held view that a large fraction of the information produced by analysts comes directly from the firm, ${ }^{7}$ it is reasonable to expect that the greater the number of analysts following a firm, the lower the level of information asymmetry between the firm and outsiders. Thus, we measure country-level "insider-outsider" information asymmetry by using the median value of analyst following, see Hope (2003), for each country in our sample period. Consistent with our hypothesis, we find that the level of analyst following has statistically significant negative impact on IPO underpricing. To represent "outsider-outsider" information symmetry, we use the stock price synchronicity from Morck et al. (2000), whereby higher level of price synchronicity represents higher level of outsideroutsider information asymmetry, after controlling for "insider-outsider" information asymmetry. ${ }^{8}$ This approach is based upon Chen et al. (2007), who discover a significant relation between price non-synchronicity and managers' investment decisions after controlling for the number of analysts. Their findings imply that managers learn from the prices of non-synchronous stocks. As expected, our empirical results indicate that stock price synchronicity is positively related to IPO underpricing.

We measure block holders' preferences for home-country equity using the measure of mutual fund home bias from Lau et al. (2009). We find a significant and negative relation between IPO underpricing and home-country bias, consistent with our hypothesis.

\footnotetext{
${ }^{3}$ Few studies have examined the relations between IPO underpricing and country-level characteristics in a multi-country framework. For example, Ljungqvist and Wilhelm (2002) examine the relations between IPO underpricing, institutional allocation, and information production through the IPO process in a sample of 641 observations from France, Germany, U.K., and U.S., but country-level determinants of IPO underpricing are not investigated. Ljungqvist et al. (2003) study the impact of diffusion of U.S. underwriting mechanisms, e.g., book building, on international IPO underpricing and direct costs of issuance.

4 A detailed discussion on our hypotheses is presented in Section 2.

5 See, for example, Allen and Faulhaber (1989), Grinblatt and Hwang (1989), Ravid and Spiegel (1997), Rock (1986), and Welch (1989).

6 Michaely and Shaw (1994) test these two hypotheses separately on U.S. data and find support for the outsider-outsider asymmetric information hypothesis. They find no support for the insider-outsider asymmetric information hypothesis (or the signaling theory). Our objective is to verify these important findings in a multi-country environment.

7 See, for example, Chen et al. (2007) and Hutton (2005).

${ }^{8}$ We do not use bid-ask spread instead of stock price synchronicity, because Stoll (1989) argues that bid-ask spread consists of three components, adverse information costs, order processing costs, and inventory holding costs. Not only the adverse information costs, but also the last two components, vary a lot across countries with vastly different institutional setups, structures of ownership and outside investors' participation rates. Thus, bid-ask spread can be a noisy proxy for adverse information costs, which we are interested in.
} 
To represent the effectiveness of a country's contract enforcement mechanisms, we use the anti-self-dealing index from Djankov et al. (2008). ${ }^{9}$ We find that the index has a significant and negative impact on IPO underpricing, which is also consistent with our hypothesis. Finally, to proxy for country-level accessibility of legal recourse, we apply the country-level prospectus liability index from La Porta et al. (2006). It varies from zero to one, with one representing the least difficulty in recovering losses due to misleading statements in the IPO prospectus, and zero representing the most. Procedural simplicity increases the ex-ante chance of litigation and makes the insurance against such litigation valuable. Consistent with our hypothesis, we find a significant positive relation between prospectus liability index and IPO underpricing.

Fortified with our results, we further check whether our main hypotheses are driven by any particular subset of our sample. First, we drop U.S. and Canada from our sample. U.S. and Canadian IPOs account for $28.28 \%$ of our sample size and in many aspects, e.g., major investment banks, number of active analysts, and number of regulatory authorities, U.S. and Canada are way ahead of most of the other countries in our sample. Thus, to examine whether our results are driven by the U.S. and Canadian IPOs, we re-estimate our model after excluding U.S. and Canadian IPOs from our sample. We find that our results are robust to exclusion/inclusion of U.S. and Canada.

Prior studies argue that governments influence asset-formation-processes significantly in Asian countries and the level of underpricing in Asian markets is driven largely by regulatory guidelines..$^{10}$ Hence, we exclude all Asian countries from our analysis and re-examine our model using the truncated sample. We find that except for the stock price synchronicity, all of our results are qualitatively similar. The coefficient on stock price synchronicity is not significant - showing that stock price synchronicity matters the most for the Asian countries. We argue that a typical uninformed Asian investor, due to relatively more government influence in asset markets, underdeveloped monitoring institutions, closely-held ownership structures widespread in Asia and, inadequate and nonfunctional "tipping laws," worries most about the existence of one or more potential outside investor(s) with relevant private information - information that helps an informed investor to select better IPOs. Thus, the uninformed outside investors demand higher protection (in form of underpricing) against potential "lemon problem" in allocation of IPOs.

Next, we drop five countries with the least number of IPOs to reduce the variability in number of IPOs across countries, and to eliminate the possibility that our results are mainly driven by a few unrepresentative countries. We re-estimate our model using this new sample and find that our results are robust. Lastly, we exclude countries with large gray markets from our sample - an over-the-counter market where dealers may execute orders for preferred customers as well as provide support for a new issue before it is actually issued. ${ }^{11}$ In such cases, IPO initial returns are lower because a market price already has been established in the gray markets, and thus, may affect our results. We re-run our model using this reduced sample and find that our results are robust to exclusion/inclusion of countries with large gray markets.

In summary, our results show that IPO underpricing is higher in countries with higher level of information asymmetry, lower level of home-country bias, less effective contract enforcement mechanism, and easier access to legal recourse for investors. The remainder of this paper is structured as follows: Section 2 reviews the literature and develops the hypotheses. Section 3 describes the sample selection process, variable definition, and summary statistics of the data. Section 4 presents the results on the relations between IPO underpricing and the main variables of interest (i.e., information asymmetry, home-country bias, effectiveness of contract enforcement, and accessibility of legal recourse). Section 5 presents the results of robustness tests and Section 6 concludes the paper.

\section{Hypothesis development}

In this section we briefly describe theories that have attempted to explain IPO underpricing. We then propose some countrylevel characteristics that can be used to test these theories, and present corresponding hypotheses.

\subsection{Asymmetric information hypothesis}

Asymmetric information theory, one of the most thoroughly explored theories of underpricing, assumes that the investors and the issuer are not equally informed, i.e., information is asymmetric and corporate transparency is limited. For example, if insiders have better information about the present value of their future cash flows than outsiders, then underpricing can be used to attract investors. ${ }^{12}$ Thus, a higher level of insider-outsider information asymmetry can be associated with a higher level of IPO underpricing. In this study, we use country-level analyst following to proxy for the level of insider-outsider information asymmetry. ${ }^{13}$ Since a higher level of analyst following is associated with a lower level of insider-outsider information asymmetry, we have the following hypothesis ${ }^{14}$ :

\footnotetext{
${ }^{9}$ This index is based on legal rules prevailing in 2003, and focuses on private enforcement mechanisms, such as disclosure, approval, and litigation, governing a specific self-dealing transaction.

${ }^{10}$ See, for example, Cheung et al. (2009) and Kutsuna et al. (2009).

11 See, for example, Derrien and Kecskes' (2007) paper for detailed discussion.

12 Underpricing could also be used to signal the company's "true" high value; see, for example, Allen and Faulhaber (1989), Grinblatt and Hwang (1989), Ravid and Spiegel (1997), and Welch (1989). This signal is clearly costly, but if successful, signaling can allow the high quality issuers to deter the low quality issuers from entering the market and the high quality issuers expect to be compensated from favorable market response in future, e.g., from seasoned equity offerings. ${ }^{13}$ See, for example, Agrawal et al. (2006), Chen et al. (2007), and Hutton (2005).

14 Bradley et al. (2003), and Cliff and Denis (2004) find that IPO firms that receive analyst coverage are more underpriced, and that these analysts tend to provide favorable recommendations for the firms. Different from this line of literature, in this paper we argue that on average analyst coverage can mitigate the information asymmetry problem in the financial market and consequently reduce IPO underpricing.
} 
Hypothesis 1a. Country-level analyst following is negatively related to IPO underpricing.

Information asymmetry among outsiders can also influence IPO underpricing. Rock (1986) model assumes that some investors are better informed about the true value of the shares on offer than other investors. Informed investors bid only for attractively priced IPOs, whereas the uninformed investors bid indiscriminately. This lack of knowledge imposes a "winner's curse" on uninformed investors: In low quality offerings, uninformed investors receive all the shares they have bid for, while in high quality offerings, their demand is largely crowded out by the informed investors. The basic testable implication of the Rock (1986) model is that, if correctly adjusted for rationing, uninformed investors' abnormal returns are zero on average. Informed investors' conditional returns are enough to cover their costs of acquiring information. Thus, we expect a higher level of outsider-outsider information symmetry to be associated with a higher level of IPO underpricing.

We use country-level stock price synchronicity to measure the level of outsider-outsider information asymmetry. Chen et al. (2007) argue that, after controlling for analyst following, the significant relation between price non-synchronicity and managers' investment decisions implies that managers learn more from the prices of non-synchronous stocks. Similarly, we argue that the information asymmetry represented by the average level of stock price synchronicity, in the presence of analyst coverage, is mainly a measure of information asymmetry among the outside investors. ${ }^{15}$

There are papers that question the effectiveness of stock price synchronicity as a proxy for information asymmetry. For example, Ashbaugh-Skaife et al. (2006), and Dasgupta et al. (2010) argue that more informative stock prices today should be associated with less firm-specific variation in stock prices in the future. Therefore, stock price synchronicity should be higher when more firm-specific information has been incorporated into the price in the past. We argue, that although this argument has its own merit, it depicts a very static nature of firm specific information. In our opinion, firm-specific information has a "level" component and a "flow" component. If flow of new information is negligible, incorporation of high level firm-specific information into the prices in the past should lead to lower firm-specific stock price variations in the future. But if the flow component is significant, then high level past incorporation may well be ineffective in taming firm-specific stock price variations in the future. What becomes important is the channel to incorporate new firm-specific information, as it evolves, into the stock prices. If these channels are not well developed - particularly the inability of the market (or country) to publicly incorporate firm-specific information into its stock prices may give rise to undesirable private channels. Uninformed investors would then require higher upfront discount in order to break even. It could be either insider based private channels or outsider based private channels; hence, we control for analyst following as a proxy of insider-outsider level of information asymmetry, and argue that stock price synchronicity as a proxy for outsider-outsider information asymmetry only after controlling for analyst following. Following hypothesis is thereby proposed:

Hypothesis 1b. Country-level stock price synchronicity is positively related to IPO underpricing.

\subsection{Enticing costs hypothesis}

The second important avenue taken by the financial literature to explain the observed IPO underpricing is related to agency costs and ownership structure. Stoughton and Zechner (1998) (henceforth, SZ) argue that underpricing helps to create block holders and thus leads to increased monitoring, which results in lower agency costs. The SZ model suggests that block holders incur costs through the lack of optimal diversification. ${ }^{16}$ We expect that in countries where investors are positively biased towards their domestic stocks, domestic investors are willing to hold proportionately more domestic equity in their portfolio - the cost to entice these investors as block holder will be relatively lower. We propose the following stylized example to put more rigor into our argument: Consider two countries, $A$ and $B$, identical in all aspects, except that country $A$ 's investor-group has positive "home bias" relative to country $B$ 's investor-group. Each country has $N$ securities traded in home market, and each investor group invests its aggregate wealth, $W$, in home as well as foreign markets.

Assume that $W_{h}^{A}$ is the wealth invested by the investor-group in country $A$ in its home market, and $W_{f}^{A}$ is the wealth invested by the investor-group in country $A$ in foreign markets. Similarly, $W_{h}^{B}$ is the wealth invested investor-group in country $B$ in the homemarket, and $W_{f}^{B}$ is the wealth invested in by investor-group in country $B$ in foreign markets. By our assumptions, we can get the following equations:

$$
\begin{aligned}
& W^{j}=W_{h}^{j}+W_{f}^{j} \quad j=A, B \\
& W^{A}=W^{B}=W \\
& W_{h}^{A}>W_{h}^{B} \text { and } W_{f}^{A}<W_{f}^{B} .
\end{aligned}
$$

Eq. (3) is based on our assumption that country A's investor-group has positive "home country bias" relative to country $B$ 's investor-group and consequently, invests a larger fraction of its aggregate wealth in home-country stocks. If both the investor-

\footnotetext{
15 Also see, for example, Durnev et al. (2003), and Durnev et al. (2004).

16 (Booth and Chua (1996) argue that underpricing might be a way to avoid block holding by creating excess demand, so that the shares can be distributed widely, while Ritter and Zhang (2007) find that deeply underpriced stocks are preferentially allocated to underwriters' affiliated funds.
} 
groups invest equally in each of the $N$ securities, then investor-group in each country invests

$$
w_{h, k}^{j}=\frac{W_{h}^{j}}{N} \quad \forall k=1,2, \ldots N, \text { and } j=A, B,
$$

in each security. Thus, together with Eq. (3), we can state that $w_{h, k}^{A}>w_{h, k}^{B} \quad \forall k=1,2, \ldots N$. If an IPO occurs in country $A$ and the investorgroup rebalances its portfolio to accommodate the newly issued security into the portfolio, then in country $A$ investor-group invests

$$
\mathbf{w}_{h, \mathrm{PO}}^{A}=\frac{W_{h}^{A}}{N+1}
$$

and,

$$
\mathbf{w}_{h, k}^{A}=\frac{W_{h}^{A}}{N+1} \quad \forall k=1,2, \ldots N
$$

where $\mathbf{w}_{h, \text { IPO }}^{A}+\sum_{k=1}^{N} \mathbf{w}_{h, k}^{A}=W_{h}^{A}$, is the total dollar invested in the domestic stock by investor-group in domestic country $A$.

If a similar IPO occurs in country $B$ and the investor-group rebalances its portfolio to accommodate the newly issued security, then in country $B$ investor-group invests

$$
\mathbf{w}_{h, \mathrm{IPO}}^{B}=\frac{W_{h}^{B}}{N+1},
$$

and,

$$
\mathbf{w}_{h, k}^{B}=\frac{W_{h}^{B}}{N+1} \quad \forall k=1,2, \ldots N .
$$

Obviously, $\mathbf{w}_{h, k}^{j}<w_{h, k}^{j}, \forall j=A, B$ and $\forall k=1, \ldots N+1$, because an increase in the number of securities decreases the dollar allocation in each security in each country. However, using Eq. (3), we can argue that investor-group in country $A$ invests more dollars in the "newly issued security" at the home-market relative to country B's investor-group, who invests less dollars in a "newly issued security" in their home-market:

$$
\mathbf{w}_{h, \mathrm{IPO}}^{A}>\mathbf{w}_{h, \mathrm{IPO}}^{B}
$$

because $W_{h}^{A}>W_{h}^{B}$. Suppose "block" position in the "newly securitized" firm implies investing $\bar{w}=\alpha V$ dollar in "newly securitized" firm in both countries $A$ and $B$, where $V$ is the fair value of the IPO firm and $\alpha$ is the required holding to act as block. Then the cost of inducing a block holder is positively related to extra dollar investment of the amount $\alpha V-\mathbf{w}_{h, \text { IPO }}^{A}$ in country $A$ and $\alpha V-\mathbf{w}_{h, \text { IPO }}^{B}$ in country $B$. Stoughton and Zechner (1998) advocate that IPO underpricing is a payment for the costs of block holding and hence, should be proportional to $\alpha V-\mathbf{w}_{h, \text { IPO }}^{A}$ in country $A$ and $\alpha V-\mathbf{w}_{h, \text { IPO }}^{B}$ in country B. Given Eq. (8), the cost of inducing "block holding" is lower in country $A$ relative to country $B$. Thus, the dollar discount, which issuing firm needs to give as compensation for the costs of excess holding, is

$$
\left.d_{A}=g\left(\alpha V-W_{h, I P O}^{A}\right)<d_{B}=g(\alpha V)-W_{h, I P O}^{B}\right),
$$

where $g(\cdot)$ is a function that converts excess exposure in a stock into costs, and the conversion depends on investors' preference parameters; $d_{A}$ and $d_{B}$ are the dollar discount to attract block holders. Since, underpricing is

$$
\frac{\text { fair value }- \text { offered value }}{\text { offered value }}
$$

and, $d_{A}$ is less than $d_{B}$ (given that $\alpha V-\mathbf{w}_{h, \text { IPO }}^{A}$ is less than $\alpha V-\mathbf{w}_{h, \text { IPO }}^{B}$ ), we get

$$
U_{A}=\frac{V-\left(V-d_{A}\right)}{V-d_{A}}<U_{B}=\frac{V-\left(V-d_{B}\right)}{V-d_{B}} .
$$

Thus, we hypothesize that IPO underpricing in country $A$ is lower than that in country $B^{17}$ :

Hypothesis 2. Country-level home-country bias is negatively related to IPO underpricing.

\footnotetext{
17 Prior studies on home-country bias show that high level information asymmetry tends to be associated with high level domestic investment bias. Also, information asymmetry tends to increase IPO underpricing. Hence, there could be a pseudo positive relation between IPO underpricing and domestic bias in the observed data. See, for example, Coval and Moskowitz (1999), and Covrig et al. (2008). In fact, we find a negative relation between the home-country bias and IPO underpricing, which strengthens our result in the sense that the observed negative relation is not driven by information asymmetry.
} 


\subsection{Contract enforcement hypothesis}

Our third hypothesis relates the country-level legal environment to IPO underpricing. It is intuitive that corporate insiders owe a duty of care and a duty of loyalty to the shareholders that they serve. Although the duty of care is easily understood, the duty of loyalty, while an easy concept to grasp intellectually, can often prove to be a troubling concept when a corporation undertakes certain types of transactions - the duty of loyalty requires that the best interests of all stakeholders take precedence over any interest possessed by a subgroup.

Conflict of interest transactions implicate the duty of loyalty because of the possibility that when a director of one corporation does a transaction with another corporation in which he has an interest, such director may be inclined to favor one corporation over the other. For example, consider the case involving a related-party transaction, where the plaintiff alleged that a stock repurchase plan inflated the price Tremont paid for stock in NL Industries. ${ }^{18}$ The plaintiff further alleged that the Tremont Board of Directors Special Committee set up to review the transaction should not have approved it, and did it because they personally benefited from the deal. Problem with such "self-dealing" cases is that these actions always benefit one group of shareholders at the expense of the others. This creates a divergence in valuation and consequently, lowers the participation of investors. Investors, who are not "connected" to the management and/or the board, stand to lose ex-post and thus react by withholding their participation ex-ante.

Choices the firm faces are as follows: Allow only a small subgroup of investors (connected group) to participate in the book building process (or auction process) and try to place as many as shares with these investors; or, reassure other (not-soconnected) investors with an upfront (ex-ante) discount and bring them on board. Basic tenet of the "increasing investors participation" is that increased participation improves visibility among investor-groups, improves market liquidity and makes it easier for the firm to raise equity-capital, if need be, in the future. Obviously, efficient country-level legal mechanisms and/or firmlevel clarity of actions against such self-dealing, also tend to reduce the ex-ante fear of "not-so-connected" investors and consequently, affect the level of discount required to make them participate. We use the anti-self-dealing index from Djankov et al. (2008) to represent the effectiveness of contract enforcement. Since a higher anti-self-dealing index represents a higher level of efficiency of private enforcement mechanisms that govern a specific self-dealing transaction, we hypothesize:

Hypothesis 3. Country-level anti-self-dealing index is negatively related to IPO underpricing.

A cross-country analysis provides us with a unique opportunity to test the contract enforcement hypothesis, which is not possible in a single country study. ${ }^{19}$ It is also important to note that the effectiveness of contract enforcement improves insideroutsider relationships and can be indirectly represented by the variables used to test the asymmetric information hypothesis. Therefore, it is an empirical question whether effective contract enforcement will still affect IPO underpricing, even after we control for the variables presenting the levels of information asymmetry.

\subsection{Litigation risk hypothesis}

Accessible and simple legal recourses tend to increase litigation risk and expose underwriters and issuers to considerable legal and punitive losses on the grounds of overstatement of gain potential and understatement of loss potential in the IPO prospectus. Lowry and Shu (2002) estimate that nearly 6\% of all companies floated in the U.S. between 1988 and 1995 subsequently were sued for various violations relating to the IPO, with average damage awarded to plaintiffs equal to $13.3 \%$ of IPO proceeds. Even though the realized loss is not that large, we should recognize the selection bias in observed lawsuits and admit that the ex ante unconditional litigation risk can be higher given that IPO underpricing tends to prevent lawsuits. Also, there is large variation in punitive damages imposed.

Therefore, our final hypothesis addresses the relation between litigation risk and IPO underpricing. We argue that IPO underpricing acts as an insurance for the issuing company and reduces the probability of lawsuit as well as the amount of damage resulting from successful litigation. ${ }^{20}$ We use the prospectus liability index from La Porta et al. (2006) to proxy for litigation risk. This index represents the level of procedural difficulty experienced by investors in recovering losses from IPO issuers, directors, distributors, and accountants as a result of misleading statements in the IPO prospectus. A larger value of the index represents a lower level of procedural difficulty in recovering losses in a civil liability case, and thus a higher level of litigation risk. Consequently, it is expected:

Hypothesis 4. Country-level prospectus liability index is positively related to IPO underpricing.

\section{Data}

In this section, we discuss our sample selection process, variable definition, and summary statistics of the data.

\footnotetext{
18 Others, for example, Kahn v. LynchCommunication Sys., 638 A.2d 1110 (Del. 1994) (merger between a controlling shareholder and the company); Wiegand v. Berry Petroleum Co., No. 9316, 1991 Del. Ch. LEXIS 37 (Del. Ch. Mar. 27, 1991) (transaction in which a majority shareholder purchased all minority shares and merged the corporation with the majority's wholly owned subsidiary); Rosenblatt v. Getty Oil Co., 493 A.2d 929 (Del. 1985) (a stock-for-stock merger between the majority and the company); Levien v. Sinclair Oil Corp., 261 A.2d 911 (Del. Ch.1969) (a dividend distribution decision relating to conflicted parent-subsidiary relationships); Sterling v. Mayflower Hotel Corp., 93 A.2d 107 (Del. Ch. 1952) (merger between a parent and a subsidiary); Gottlieb v. Heyden Chem. Corp., 91 A.2d 57 (Del. 1952) (decision by certain stockholders of a corporation to issue themselves stock options without obtaining stockholder ratification).

${ }^{19}$ Similarly, see, for example, Hopp and Dreher (2010).

20 See, for example, Hughes and Thakor (1992), and Tinic (1988).
} 


\subsection{Sample selection}

Our data on IPOs are obtained from the Global New Issue Database provided by Thomson Financial Securities Data Company (SDC) Platinum. We start with 13,772 observations on international common stock issues from January 1, 2000 through December 31 , 2006. After excluding private placements, in which the securities are sold directly to some private investors and not widely listed, we obtain a sample with 13,386 international IPOs.

We calculate IPO underpricing as the percentage difference between the offer price and the first day closing price in SDC. If the first day closing price in SDC is missing, we try to replace the missing value with the earliest closing price within one week subsequent to the IPO issue date (i.e., the second day, third day, or first week closing price) in SDC. If we cannot find any appropriate closing price in SDC, we will try to use the daily closing price from DataStream. Similarly, we require the closing price in DataStream to be the earliest daily closing price within 10 days subsequent to the IPO issue date specified in SDC. ${ }^{21}$ We then perform the following steps to filter the sample with 13,386 IPOs:

(1) We exclude IPOs with missing values of closing price and/or offer price (3529 IPOs are excluded).

(2) We delete IPOs with abnormal high or low values of underpricing, i.e., higher than $2000 \%$ or lower than $-67 \%$ (161 IPOs are excluded). ${ }^{22}$

(3) We require deal-specific control variables, and market-specific control variables to be non-missing (919 IPOs are excluded). ${ }^{23}$

(4) We drop one country (Pakistan) only with one qualified and reported IPO between January 1, 2000 and December 31, 2006.

Hence, we end up with a sample of 8776 IPOs from 36 countries. To further mitigate the potential effects of data errors, we winsorize IPO underpricing at 0.5 percentile and 99.5 percentile of the finalized sample.

\subsection{Variable definition}

The main variables of interest in testing our hypotheses are: Analyst following, Stock price synchronicity, Home-country bias, Anti-self-dealing index, and Prospectus liability index. The definitions and sources of these variables are discussed below in details.

(1) Analyst Following: We follow Hope (2003) methodology and calculate our analyst following measure to test Hypothesis 1a. ${ }^{24}$ Hope's sample is based on Center for International Financial Analysis and Research (CIFAR), which only covers the largest firms from each sample country. To avoid this large-firm bias, we estimate "analyst following" directly based upon $I / B / E / S$ Summary Statistics Database and do not require the firms to be of any particular size. We first calculate firm-year analyst following $\left(a f_{i j t}\right.$ ) as the number of analysts who follow firm $i$ in country $j$ by issuing one-year-ahead EPS forecasts for every fiscal year $t$. Then, we calculate the median value of $a f_{i j t}$ in country $j$ during the sample period from 2000 to 2006 as the measure of country-level analyst following $\left(a f_{j}\right)$. The expected sign of the coefficient on analyst following as a determinant of IPO underpricing is negative. This variable is held constant for a country in our sample period.

(2) Stock Price Synchronicity: We use country-level stock price synchronicity developed by Morck et al. (2000) to test Hypothesis $1 \mathrm{~b}$. Morck et al. (2000) estimate stock price synchronicity as the proportion of stocks moving in step for 40 countries based on the DataStream data. They calculate the fraction of stocks that move in the same direction in any country $j$ as:

$$
\text { Synchronicity }_{j}=\sum_{t}\left[\left(\max \left(n_{\text {up }, j t}, n_{\text {down }, j t}\right)\right) /\left(n_{u p, j t}+n_{\text {down }, j t}\right)\right] / T \text {, }
$$

where $n_{u p, j t}$ is the number of stocks in country $j$ whose prices rise in week $t, n_{\text {down, } j t}$ is the number of stocks whose prices fall, and $T$ is the number of weeks in their sample period. We expect the sign of the coefficient on stock price synchronicity as a determinant of IPO underpricing to be positive. We get the data on stock price synchronicity directly from Morck et al. (2000). This variable is held constant for a country in our sample period.

(3) Home-country Bias: To test our Hypothesis 2, we use country-level measure of home-country bias developed by Lau et al. (2009). This measure is calculated based on the percentage of home mutual fund of country $j$ invested in home stocks of country $j\left(w_{j j}\right)$ compared to the home stock market capitalization weight of country $j$ in the world market $\left(w_{j}^{*}\right)$. Specifically, the home bias is expressed in natural logarithm form, i.e., home bias is equal to $\ln \left(w_{j j} / w_{j}^{*}\right)$. Lau et al. (2009) calculate the measure of home-country bias based on Thomson Reuters' mutual fund database for 38 countries in the sample period between 1998 and 2007. Our expected sign of the coefficient on home-country bias as a determinant of IPO underpricing is negative. We get the data on home-country bias directly from Lau et al. (2009). This variable is held constant for a country in our sample period.

\footnotetext{
${ }^{21}$ We link IPO observations in SDC to trading prices in DataStream by SEDOL number. The closing price in DataStream is treated as a missing value when it is exactly equal to the offer price in SDC.

22 Among the 161 dropped IPOs, 109 values of underpricing are negative, with mean value equal to - 92\% and median value equal to - 95\%, while $43 \%$ of these negative underpricing values are lower than or equal to $-99 \%$. For the 52 excluded IPOs with positive values of underpricing, the mean value of undperpricing is $23,216 \%$ and the median value is $5899 \%$, while the minimum value of underpricing is $2110 \%$. Therefore, we believe these extreme values of underpricing are possibly caused by the potential data errors to a large extent, and exclude them from our analysis. However, our results still remained as qualitatively similar, when we keep these IPOs in our sample and winsorize IPO underpricing at 1 percentile and 99 percentile in the full sample. The results are also qualitatively similar, when other combinations of cut-off points are used (e.g., $1500 \%$ and $-50 \%, 1000 \%$ and $-30 \%$, and $2500 \%$ and $-80 \%$ ).

23 We will discuss these control variables in details in the next subsection.

24 Hope (2003) estimates analyst following for a sample of 22 countries to investigate the determinants of analysts' earnings forecast accuracy.
} 
(4) Anti-self-dealing: We use country-level anti-self-dealing index to test our Hypothesis 3. Djankov et al. (2008) construct antiself-dealing index based on a questionnaire by attorneys from Lex Mundi, which is an association of international law firms. It ranges from zero to one, with one representing the highest level of legal protection of minority shareholders against expropriation by corporate insiders, and zero representing the lowest level of legal protection. The expected sign of the coefficient on anti-self-dealing index as a determinant of IPO underpricing is negative. We get the data on anti-self-dealing index directly from Professor Rafael La Porta's website. This variable is held constant for a country in our sample period. ${ }^{25}$

(5) Prospectus Liability: We use country-level prospectus liability index to test our Hypothesis 4, which is an index of procedural difficulty in recovering losses in a civil liability case due to misleading statements in the IPO prospectus La Porta et al. (2006). Specifically, the liability index equals the arithmetic mean of liability standards for recovering losses from 1) issuer and its directors, 2) distributors, and 3) accountants. It varies from zero to one, with one representing the least difficulty in recovering losses (the highest litigation risk), and zero representing the most difficulty (the lowest litigation risk). We expect the sign of the coefficient on prospectus liability index as a determinant of IPO underpricing to be positive. We get the data on prospectus liability index directly from Professor Rafael La Porta's website. This variable is held constant for a country in our sample period.

We control for other variables documented in the literature to explain IPO underpricing:

- Offer Size: Beatty and Ritter (1986) use the inverse of the gross proceeds as a proxy for information uncertainty. They find that empirically smaller offerings are more speculative on average than larger offerings. Specifically, they show a significant and positive relation between the reciprocal of gross proceeds and IPO underpricing. ${ }^{26}$ Following Smart and Zutter (2003), we use the logarithm of IPO offer size adjusted by CPI to control for the size effect and expect its coefficient to be negative. Our data source of IPO offer size is SDC database.

- Integer Offer Price: Bradley et al. (2004) hypothesize that fractional offer price is a result of negotiation between the issuing firm and underwriter. Therefore, the presence of integer offer price should be related to a larger degree of firm value uncertainty. They find IPOs with integer offer prices are underpriced more than those with fractional offer prices. We define a dummy variable to represent the presence of integer offer price. The expected sign of the coefficient on integer offer price dummy is positive. Our data source of integer offer price dummy is SDC database.

- Book Building: According to Sherman (2005), book building allows underwriters to manage investors' access to shares allocation and reduces risk for both issuers and investors. Consequently, underwriters can control the cost on information acquisition, and hereby limit either underpricing or ex-post market volatility in book-built IPOs. Thus, we expect the coefficient sign of the book building dummy to be negative. Our data source of book building dummy is SDC database.

- Equity Carve Out: Prezas et al. (2000) find significantly lower initial returns for carve-out IPOs compared to original IPOs matched by size and equity book-to-market ratio. Thus, a dummy variable representing equity carve-out deal is expected to have a negative coefficient. Our data source of equity carve out dummy is SDC database.

- Underwriter Reputation: Earlier empirical findings show that the underwriters with higher reputation should be able to make the IPO price closer to the intrinsic value, i.e., lower IPO underpricing (Carter and Manaster (1990); Carter et al. (1998)). However, Loughran and Ritter (2004) find that in 1990s higher reputation underwriters are associated with higher IPO underpricing. To control for this ambiguous effect, we construct a measure of underwriter reputation similar to Megginson and Weiss (1991), which is a decile-reputation rank of underwriter's global market share from 2000 to 2006. If an IPO has multiple underwriters, the proceeds of this IPO will be evenly split and assigned to each underwriter's market share. Then, after obtaining the decilereputation rank for each underwriter, we pick up the highest reputation rank among all the underwriters for each IPO. The highest rank of underwriter reputation is ten and represents the highest decile of global IPO market share, while the lowest reputation rank is one and represents the lowest decile of market share. We do not have an explicit prediction on the coefficient of underwriter reputation. Our data source of underwriter reputation is SDC database.

- Market Return: (Ritter (1984) finds that the average initial IPO return is higher in the hot issue period compared to that in the cold issue period. Furthermore, Ljungqvist et al. (2006) presents a model in which they show that regular investors are compensated by IPO underpricing for the expected losses when the hot market crashes in future. To control for this effect, we estimate the cumulative local market return over last three months before the IPO issue date based on DataStream market index for each country. We expect the coefficient of market return to be positive. Our data source of market return is DataStream database.

- IPO Hot/Cold: To further control for the hot market effects as suggested by Ritter (1984), we define and control for IPO hot/cold for each country-year combination as the ratio of IPO number in a particular year over the total IPO number during the period of 20002006 for each country. We expect the coefficient of IPO hot/cold to be positive too. Our data source of IPO hot/cold is SDC database.

- Stock Turnover: Lowry and Shu (2002) argue that higher levels of stock turnover are related to higher levels of plaintiffs' incentives to initiate lawsuits, because shareholder damages increase with the number of shares traded at allegedly misleading prices. They use the average stock turnover of a matched sample over the one year prior to the IPO to proxy for the IPO firm's stock turnover. The matched sample consists of firms in the same three-digit SIC code with comparable market capitalization. Using simultaneous-equation approach, Lowry and Shu (2002) find that sued firms have higher stock turnover, while higher stock turnover is associated with higher IPO underpricing on average. To control for this turnover effect, we follow the definition used by Beck et al. (2000), in which the

\footnotetext{
25 Since the response to the questionnaire by the attorneys is voluntary and the implications of systematic negative responses about the legal system may vary from country to country, there are some elements of selection bias in anti-self-dealing index. We try to control for such bias by looking at sub samples with no perceived consequences associated with unfavorable response.

${ }^{26}$ Arugaslan et al. (2004), and Habib and Ljungqvist (1998) point out some limitations of using this variable as a proxy for information uncertainty.
} 
Table 1

Summary statistics of IPO underpricing by country. This table presents the mean and median value of IPO underpricing, and the number of IPOs for each country in the full sample with 8776 IPOs from 2000 to 2006. IPO underpricing is the percentage return from the offer price to the first closing price.

\begin{tabular}{|c|c|c|c|}
\hline Nation & Mean & Median & $\mathrm{N}$ \\
\hline Australia & 16.59 & 5.08 & 696 \\
\hline Austria & 23.76 & 3.35 & 34 \\
\hline Belgium & 10.36 & 3.79 & 32 \\
\hline Brazil & 18.37 & 7.67 & 46 \\
\hline Canada & 39.13 & 6.02 & 784 \\
\hline China & 57.14 & 33.43 & 590 \\
\hline Denmark & 13.48 & 6.67 & 27 \\
\hline Finland & 14.61 & 2.44 & 25 \\
\hline France & 11.30 & 2.29 & 353 \\
\hline Germany & 43.13 & 15.65 & 333 \\
\hline Greece & 14.44 & 2.29 & 53 \\
\hline Hong Kong & 22.21 & 5.26 & 479 \\
\hline India & 25.01 & 18.90 & 9 \\
\hline Indonesia & 52.25 & 23.11 & 48 \\
\hline Ireland & 10.29 & 11.73 & 25 \\
\hline Israel & 23.34 & 11.90 & 42 \\
\hline Italy & 7.87 & 0.85 & 215 \\
\hline Japan & 45.14 & 20.71 & 890 \\
\hline Luxembourg & 26.68 & 25.00 & 15 \\
\hline Malaysia & 31.18 & 14.21 & 295 \\
\hline Netherlands & 20.00 & 4.94 & 44 \\
\hline New Zealand & 20.66 & 3.33 & 38 \\
\hline Norway & 4.33 & 0.80 & 45 \\
\hline Philippines & 17.27 & 4.00 & 19 \\
\hline Poland & 45.50 & 16.81 & 23 \\
\hline Russia & 8.82 & 8.00 & 10 \\
\hline Singapore & 24.88 & 9.47 & 296 \\
\hline South Africa & 12.94 & 9.60 & 18 \\
\hline South Korea & 54.57 & 36.18 & 192 \\
\hline Spain & 10.98 & 5.88 & 45 \\
\hline Sweden & 21.79 & 7.24 & 73 \\
\hline Switzerland & 14.41 & 4.75 & 39 \\
\hline Taiwan & 17.25 & 6.70 & 260 \\
\hline Thailand & 19.15 & 5.11 & 143 \\
\hline United Kingdom & 23.29 & 9.21 & 840 \\
\hline United States & 24.00 & 5.00 & 1700 \\
\hline All & 29.11 & 8.18 & 8776 \\
\hline
\end{tabular}

turnover is defined as the ratio of total value of shares traded over stock market capitalization. We estimate this ratio for each country and each year, and expect the coefficient of stock turnover to be positive. Our data source is DataStream database.

\subsection{Summary statistics}

Table 1 summarizes the mean and median value of IPO underpricing, and the number of IPOs for each country in our sample period of 2000-2006. U.S. has the largest number of IPOs in our sample with 1700 IPOs, followed by Japan and U.K. with 890 and 840 IPOs respectively. India has 9 IPOs, the lowest number of IPOs in our sample. ${ }^{27}$ Norway has the lowest mean and median value of IPO underpricing equal to $4.33 \%$ and $0.80 \%$, followed by Italy with mean and median value of IPO underpricing equal to $7.87 \%$ and $0.85 \%$. China has the highest mean value of IPO underpricing equal to $57.14 \%$, while South Korea has the highest median value of IPO underpricing equal to $36.18 \%$.

Table 2 presents the country-level variables of our main interests in testing the hypotheses. Spain has the largest estimate of analyst following equal to 12 , and Israel has the smallest estimate of analyst following equal to 2 . The estimate of stock price synchronicity varies from the lowest value of 57.90 in U.S. to the highest value of 82.90 in Poland. ${ }^{28}$ Home country bias is lowest in U.S. equal to 0.70 and highest in Philippines equal to 6.71. In Singapore, the anti-self-dealing index is highest at 1.00, while in Netherlands it is lowest at 0.20 . Prospectus liability index is highest at 1.00 (highest litigation risk) in U.S., Canada, and Philippines, while it is lowest at 0.00 in Germany. Moreover, not all of the country-level variables are non-missing in the sample. For example, analyst following estimate is missing for Thailand. The estimates of stock price synchronicity are missing for Israel, Luxembourg, Russia, and Switzerland in Morck et al. (2000) while home-country bias measures for Indonesia, Israel, Russia, and South Korea are not presented in Lau et al. (2009). Lastly, prospectus liability index is missing for China, Luxembourg, Poland, and Russia.

Table 3 shows the summary statistics of the variables. Nearly half of the IPOs have integer offer prices in their home-country currencies. Underwriters use book-building technique to allocate shares among the investors in $62 \%$ of IPOs. Approximately $6 \%$ of IPOs are

\footnotetext{
27 We delete Pakistan that has only one qualified and reported IPO between 2000 and 2006.

28 This measure implies that on average approximately $58 \%$ of the stock prices in U.S. move together in the same direction at any given week.
} 
Table 2

Country-level variables of main interests. This table presents the country-level variables of our main interests in the full sample with 8776 IPOs from 2000 to 2006 . These variables are held constant for each country in our sample period. The variables of main interests include Analyst Following (AF), Stock Price Synchronicity (SPS), Homecountry Bias (HCB), Anti-self-dealing Index (ASD), and Prospectus Liability Index (PL). Analyst following is the median value of firm-year analyst following estimates. Stock price synchronicity is the percentage of stocks moving in step. Home-country bias is the logarithm value of the ratio of home mutual fund investment weight in home stocks over the home stock market capitalization weight in the world market. Anti-self-dealing index represents the level of legal protection of minority shareholders against expropriation by corporate insiders. Prospectus liability index is an index of procedural difficulty in recovering losses in a civil liability case due to misleading statements in the IPO prospectus.

\begin{tabular}{|c|c|c|c|c|c|}
\hline Nation & $\mathrm{AF}$ & SPS & HCB & ASD & PL \\
\hline Australia & 5.00 & 61.40 & 3.96 & 0.76 & 0.66 \\
\hline Austria & 4.00 & 66.20 & 4.91 & 0.21 & 0.11 \\
\hline Belgium & 5.00 & 65.00 & 3.31 & 0.54 & 0.44 \\
\hline Brazil & 6.00 & 64.70 & 4.95 & 0.27 & 0.33 \\
\hline Canada & 5.00 & 58.30 & 2.27 & 0.64 & 1.00 \\
\hline China & 3.00 & 80.00 & 3.99 & 0.76 & / \\
\hline Denmark & 5.00 & 63.10 & 4.11 & 0.46 & 0.55 \\
\hline Finland & 8.00 & 68.90 & 4.43 & 0.46 & 0.66 \\
\hline France & 8.00 & 59.20 & 2.65 & 0.38 & 0.22 \\
\hline Germany & 8.00 & 61.10 & 2.17 & 0.28 & 0.00 \\
\hline Greece & 5.00 & 69.70 & 5.63 & 0.22 & 0.50 \\
\hline Hong Kong & 9.00 & 67.80 & 2.34 & 0.96 & 0.66 \\
\hline India & 6.00 & 69.50 & 4.98 & 0.58 & 0.66 \\
\hline Indonesia & 6.00 & 67.10 & / & 0.65 & 0.66 \\
\hline Ireland & 4.00 & 65.70 & 2.20 & 0.79 & 0.44 \\
\hline Israel & 2.00 & / & / & 0.73 & 0.66 \\
\hline Italy & 7.00 & 66.60 & 3.03 & 0.42 & 0.22 \\
\hline Japan & 4.00 & 66.60 & 2.36 & 0.50 & 0.66 \\
\hline Luxembourg & 3.00 & / & 4.54 & 0.28 & / \\
\hline Malaysia & 6.00 & 75.40 & 5.44 & 0.95 & 0.66 \\
\hline Netherlands & 9.00 & 64.70 & 2.91 & 0.20 & 0.89 \\
\hline New Zealand & 4.00 & 64.60 & 6.52 & 0.95 & 0.44 \\
\hline Norway & 5.00 & 66.60 & 5.29 & 0.42 & 0.39 \\
\hline Philippines & 6.00 & 68.80 & 6.71 & 0.22 & 1.00 \\
\hline Poland & 4.00 & 82.90 & 6.69 & 0.29 & / \\
\hline Russia & 4.00 & / & / & 0.44 & / \\
\hline Singapore & 5.00 & 69.70 & 3.52 & 1.00 & 0.66 \\
\hline South Africa & 5.00 & 67.20 & 4.54 & 0.81 & 0.66 \\
\hline South Korea & 3.00 & 70.30 & / & 0.47 & 0.66 \\
\hline Spain & 12.00 & 67.00 & 2.94 & 0.37 & 0.66 \\
\hline Sweden & 6.00 & 66.10 & 3.93 & 0.33 & 0.28 \\
\hline Switzerland & 7.00 & / & 2.17 & 0.27 & 0.44 \\
\hline Taiwan & 3.00 & 76.30 & 4.51 & 0.56 & 0.66 \\
\hline Thailand & / & 67.40 & 6.09 & 0.81 & 0.22 \\
\hline United Kingdom & 4.00 & 63.10 & 1.71 & 0.95 & 0.66 \\
\hline United States & 6.00 & 57.90 & 0.70 & 0.65 & 1.00 \\
\hline
\end{tabular}

equity carve-out IPOs. Median value of underwriter reputation is 10, which indicates more than half IPOs are underwritten by top-decile reputed investment banks. On average, three-month market return prior to IPO issuance date is $2.26 \%$. The average value of IPO hot/cold indicator is 0.18 , while the mean value of stock market turnover is 0.98 .

Table 4 shows the correlation coefficients of the variables of interest. Consistent with our asymmetric information hypothesis, we find the correlation coefficient between IPO underpricing and analyst following is -0.10 (significant at $1 \%$ ), while the correlation coefficient between IPO underpricing and stock price synchronicity is 0.09 (significant at $1 \%$ level). The correlation coefficient of IPO underpricing and home-country bias is positive but insignificant and close to zero. The correlation coefficient between IPO underpricing and anti-self-dealing index is -0.02 (significant at $10 \%$ level), while the correlation coefficient between IPO underpricing and prospectus liability index is 0.03 (significant at $5 \%$ level). Both of these two coefficients are consistent with our contract enforcement hypothesis and litigation risk hypothesis. In the next section, we will further test our four hypotheses in multivariate regressions, although in the univariate analysis results are generally consistent (except for enticing costs hypothesis).

\section{Results}

To test our hypotheses, we estimate multivariate regressions, which consist of Fama-French 48 industry dummies (Fama and French (1997)) and year dummies with Huber/White robust standard errors. Our main variables of interest are Analyst Following, Stock Price Synchronicity, home-country bias, anti-self-dealing index, and prospectus liability index. We also control for dealspecific variables (log offer size, integer offer price dummy, book building dummy, equity carve-out dummy, and underwriter reputation), as well as market-specific variables (market return, IPO hot/cold, and stock turnover). 
Table 3

Summary statistics of variables. This table presents the mean, quartiles, and standard deviation of the variables in the full sample with 8776 IPOs from 2000 to 2006 . IPO underpricing is the percentage return from the offer price to the first closing price. Analyst following is the median value of firm-year analyst following estimates. Stock price synchronicity is the percentage of stocks moving in step. Home-country bias is the logarithm value of the ratio of home mutual fund investment weight in home stocks over the home stock market capitalization weight in the world market. Anti-self-dealing index represents the level of legal protection of minority shareholders against expropriation by corporate insiders. Prospectus liability index is an index of procedural difficulty in recovering losses in a civil liability case due to misleading statements in the IPO prospectus. Log offer size is the logarithm value of IPO offer size. Integer offer price indicates one when offer price is integer in home-country currency. Book building indicates one when the underwriter chooses book-building as pricing technique. Equity carve-out indicates one when the issue is a carve-out deal. Underwriter reputation is the decile-reputation rank of underwriter's global market share. Market return is the cumulative local market return over last three months before the IPO issue date. IPO hot/cold is the ratio of IPO number in one year over the total IPO number during our sample period. Stock turnover is the ratio of total value of shares traded over stock market capitalization for each year and each country.

\begin{tabular}{|c|c|c|c|c|c|c|}
\hline & Mean & Q1 & Median & Q3 & Std & $\mathrm{N}$ \\
\hline IPO Underpricing & 29.11 & 0.00 & 8.18 & 31.54 & 63.40 & 8776 \\
\hline Analyst Following & 5.36 & 4.00 & 5.00 & 6.00 & 1.72 & 8633 \\
\hline Stock Price Synchronicity & 64.67 & 58.30 & 63.10 & 67.80 & 6.59 & 8670 \\
\hline Home-country Bias & 2.64 & 1.71 & 2.36 & 3.96 & 1.45 & 8484 \\
\hline Anti-self-dealing Index & 0.67 & 0.50 & 0.65 & 0.76 & 0.21 & 8776 \\
\hline Prospectus Liability Index & 0.69 & 0.66 & 0.66 & 1.00 & 0.27 & 8138 \\
\hline Log Offer Size & 3.09 & 1.82 & 2.99 & 4.26 & 1.64 & 8776 \\
\hline Integer Offer Price & 0.50 & 0.00 & 0.00 & 1.00 & 0.50 & 8776 \\
\hline Book Building & 0.62 & 0.00 & 1.00 & 1.00 & 0.49 & 8776 \\
\hline Equity Carve-out & 0.06 & 0.00 & 0.00 & 0.00 & 0.24 & 8776 \\
\hline Underwriter Reputation & 8.98 & 9.00 & 10.00 & 10.00 & 1.89 & 8776 \\
\hline Market Return & 2.26 & -1.72 & 2.44 & 6.31 & 7.54 & 8776 \\
\hline IPO Hot/Cold & 0.18 & 0.12 & 0.16 & 0.21 & 0.11 & 8776 \\
\hline Stock Turnover & 0.98 & 0.61 & 0.85 & 1.36 & 0.50 & 8776 \\
\hline
\end{tabular}

The results in model M-1 of Table 5, which includes all the control variables without any of the main variables related to our hypotheses, are presented for completeness and comparison purpose as follows:

$$
\begin{aligned}
\mathrm{U}_{i j t}= & \alpha+\gamma_{\text {Deal }} * \text { Deal Controls } \\
& +\delta_{\text {Industry }}+\gamma_{\text {Market }} * \text { Market Controls } \\
& \text { Indry Dummies }+\delta_{t} * \text { Year Dummies }+\varepsilon_{i j t},
\end{aligned}
$$

where $\mathrm{U}_{i j t}$ is the percentage underpricing of firm $i$ that go public in country $j$ at year $t$. Deal Controls $s_{i j t}$ represent deal specific control variables, and Market Controls $s_{i j t}$ represent market specific control variables.

The coefficient on log offer size is negative $(-5.22)$ and significant at $1 \%$ level. This result is consistent with Beatty and Ritter (1986), who find that small-size IPOs are more speculative than large-size IPOs. Sherman (2005) argues that underwriters can control costs on information acquisition, and consequently reduce IPO underpricing by using book building technique. Consistently, we find that the coefficient on book building dummy in model M-1 is negative $(-5.89)$ and significant at $1 \%$ level. ${ }^{29}$ We find that the coefficient on equity carve-out dummy is -4.47 and significant at $5 \%$ level, which suggests that carve-out IPOs on average contains more information than normal IPOs (Prezas et al. (2000)). Similar to the findings in Loughran and Ritter (2004), we find that the coefficient associated with underwriter reputation is positive and significant at $5 \%$ level (coefficient is 0.93 , and t-value is 2.07 ). The coefficients on both market return and IPO hot/cold are positive and significant (coefficients are 0.83 and 23.52 respectively). These results indicate that IPO underpricing is higher in the hot issue period than in the cold period (Ljungqvist et al. (2006); Ritter (1984)). The coefficient on stock turnover is consistent with Lowry and Shu (2002) (coefficient is 8.65 and significant at 1\% level), which suggests that higher stock turnover is associated with higher IPO underpricing.

\subsection{Tests on asymmetric information hypothesis}

In this subsection, we test our asymmetric information hypothesis: insider-outsider (Hypothesis 1a) asymmetric information hypothesis and outsider-outsider (Hypothesis $1 \mathrm{~b}$ ) asymmetric information hypothesis.

\subsubsection{Tests on insider-outsider asymmetric information hypothesis}

To test insider-outsider asymmetric information hypothesis (Hypothesis 1a), we perform following regression of IPO underpricing on the estimate of analyst following:

$$
\begin{aligned}
\mathrm{U}_{i j t}= & \alpha+\beta_{A F} * \text { Analyst Following }_{j}+\gamma_{\text {Deal }} * \text { Deal Controls } \\
& +\gamma_{\text {Market }} * \text { Market Controls } \\
& +\delta_{t} * \text { Year Dummies }+\varepsilon_{i j t} .
\end{aligned}
$$

The variable of our main interest, Analyst Following; , is held constant in the entire sample period for each country. The result is presented in model M-2. Consistent with Hypothesis 1a, we find that higher level of IPO underpricing is associated with lower country-level analyst following estimate (coefficient on analyst following is -3.97 and significant at $1 \%$ level).

\footnotetext{
${ }^{29}$ This result is also consistent with Ljungqvist et al. (2003), in which they find that using U.S. underwriting mechanisms, e.g., book building technique, tends to reduce IPO underpricing in other countries.
} 
Table 4

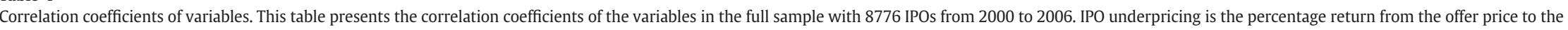

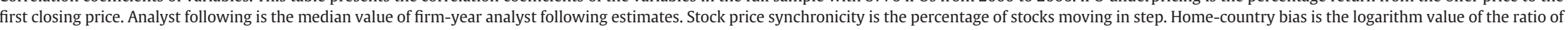

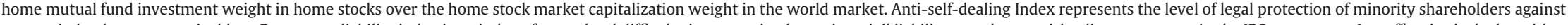

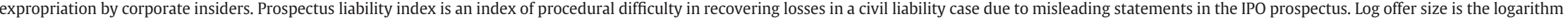

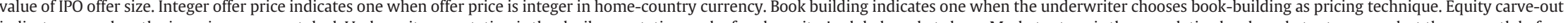

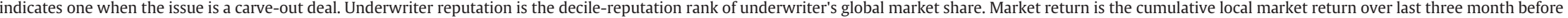

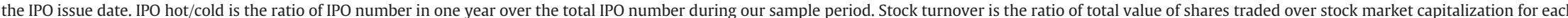
year and each country.

\begin{tabular}{|c|c|c|c|c|c|c|c|c|c|c|c|c|c|c|}
\hline & $\begin{array}{l}\text { I P O } \\
\text { underpricing }\end{array}$ & $\begin{array}{l}\text { A n a ly s t } \\
\text { following }\end{array}$ & $\begin{array}{l}\text { Stock price } \\
\text { synchronicity }\end{array}$ & $\begin{array}{l}\mathrm{H} \mathrm{o} \mathrm{m} \mathrm{e} \mathrm{-} \\
\text { country bias }\end{array}$ & $\begin{array}{l}\text { Anti-self- } \\
\text { dealing }\end{array}$ & $\begin{array}{l}\text { Prospectus } \\
\text { liability }\end{array}$ & $\begin{array}{l}\text { Log offer } \\
\text { size }\end{array}$ & $\begin{array}{l}\text { Integer offer } \\
\text { price }\end{array}$ & $\begin{array}{l}\text { B o o k } \\
\text { building }\end{array}$ & $\begin{array}{l}\text { E q u i t y } \\
\text { carve-out }\end{array}$ & $\begin{array}{l}\text { Underwriter } \\
\text { reputation }\end{array}$ & $\begin{array}{l}\text { M a r k e t } \\
\text { return }\end{array}$ & $\begin{array}{l}\text { IPO hot/ } \\
\text { cold }\end{array}$ & $\begin{array}{l}\mathrm{St} \mathrm{o} \mathrm{c} \mathrm{k} \\
\text { turnover }\end{array}$ \\
\hline IPO Underpricing & 1.00 & & & & & & & & & & & & & \\
\hline $\begin{array}{l}\text { A } \mathrm{n} \mathrm{a} \mathrm{l} \mathrm{y} \mathrm{s} \mathrm{t} \\
\text { Following }\end{array}$ & -0.10 & 1.00 & & & & & & & & & & & & \\
\hline $\begin{array}{l}\text { Stock Price } \\
\text { Synchronicity }\end{array}$ & 0.09 & -0.38 & 1.00 & & & & & & & & & & & \\
\hline $\begin{array}{l}\text { Home-country } \\
\text { Bias }\end{array}$ & 0.00 & -0.23 & 0.68 & 1.00 & & & & & & & & & & \\
\hline $\begin{array}{l}\text { Anti-self-dealing } \\
\text { Index }\end{array}$ & -0.02 & -0.16 & 0.18 & 0.04 & 1.00 & & & & & & & & & \\
\hline $\begin{array}{l}\text { P r o s p e c t u s } \\
\text { Liability Index }\end{array}$ & 0.03 & -0.25 & -0.36 & -0.49 & 0.32 & 1.00 & & & & & & & & \\
\hline Log Offer Size & -0.13 & 0.09 & -0.16 & -0.30 & -0.19 & 0.13 & 1.00 & & & & & & & \\
\hline $\begin{array}{l}\text { Integer Offer } \\
\text { Price }\end{array}$ & -0.01 & 0.01 & -0.25 & -0.29 & -0.44 & 0.12 & 0.34 & 1.00 & & & & & & \\
\hline Book Building & -0.05 & 0.15 & -0.26 & -0.48 & -0.30 & -0.08 & 0.37 & 0.23 & 1.00 & & & & & \\
\hline Equity Carve-out & -0.06 & 0.09 & 0.02 & 0.02 & -0.12 & -0.12 & 0.25 & 0.00 & 0.16 & 1.00 & & & & \\
\hline $\begin{array}{l}\text { Und e r w r i t e r } \\
\text { Reputation }\end{array}$ & -0.03 & 0.02 & -0.05 & -0.22 & -0.12 & 0.04 & 0.44 & 0.24 & 0.36 & 0.12 & 1.00 & & & \\
\hline Market Return & 0.10 & -0.02 & 0.03 & 0.10 & -0.07 & -0.09 & 0.02 & 0.01 & -0.05 & -0.04 & -0.02 & 1.00 & & \\
\hline IPO Hot/Cold & 0.12 & 0.24 & -0.09 & 0.02 & -0.29 & -0.33 & 0.00 & 0.15 & 0.13 & -0.02 & 0.07 & 0.12 & 1.00 & \\
\hline Stock Turnover & 0.04 & -0.13 & -0.24 & -0.55 & -0.09 & 0.35 & 0.29 & 0.29 & 0.35 & 0.01 & 0.17 & -0.07 & 0.15 & 1.00 \\
\hline
\end{tabular}


Table 5

Regression results of IPO underpricing. This table presents the regression results of IPO underpricing in the full sample with 8776 IPOs from 2000 to 2006 . Sample size will be reduced when certain main variables of interest are required to be non-missing. IPO underpricing is the percentage return from the offer price to the first closing price. Analyst following is the median value of firm-year analyst following estimates. Stock price synchronicity is the percentage of stocks moving in step. Home-country bias is the logarithm value of the ratio of home mutual fund investment weight in home stocks over the home stock market capitalization weight in the world market. Anti-self-dealing index represents the level of legal protection of minority shareholders against expropriation by corporate insiders. Prospectus liability index is an index of procedural difficulty in recovering losses in a civil liability case due to misleading statements in the IPO prospectus. Log offer size is the logarithm value of IPO offer size. Integer offer price indicates one when offer price is integer in home-country currency. Book building indicates one when the underwriter chooses book-building as pricing technique. Equity carve-out indicates one when the issue is a carve-out deal. Underwriter reputation is the decile-reputation rank of underwriter's global market share. Market return is the cumulative local market return over last three months before the IPO issue date. IPO hot/cold is the ratio of IPO number in one year over the total IPO number during our sample period. Stock turnover is the ratio of total value of shares traded over stock market capitalization for each year and each country. t-values are reported in parentheses. ${ }^{* * *}$,** $^{*}$ and * stand for statistical significance based on a twosided $t$ test at the $1 \%, 5 \%$ and $10 \%$ levels, respectively. All regressions control for year fixed effects and industry fixed effects.

\begin{tabular}{|c|c|c|c|c|c|c|c|}
\hline & M1 & M2 & M3 & M4 & M5 & M6 & M7 \\
\hline Analyst Following & & $\begin{array}{l}-3.97^{* * *} \\
(-9.21)\end{array}$ & $\begin{array}{l}-3.46^{* * *} \\
(-7.10)\end{array}$ & & & & $\begin{array}{l}-2.57^{* * *} \\
(-5.09)\end{array}$ \\
\hline Stock Price Synchronicity & & & $\begin{array}{l}0.53^{* * *} \\
(3.58)\end{array}$ & & & & $\begin{array}{l}0.74^{* * *} \\
(3.55)\end{array}$ \\
\hline Home-country Bias & & & & $\begin{array}{l}-1.29^{*} \\
(-1.80)\end{array}$ & & & $\begin{array}{l}-6.57^{* * * *} \\
(-6.59)\end{array}$ \\
\hline Anti-self-dealing Index & & & & & $\begin{array}{l}-7.66^{* *} \\
(-2.11)\end{array}$ & & $\begin{array}{l}-21.91^{* * *} \\
(-4.99)\end{array}$ \\
\hline Prospectus Liability Index & & & & & & $\begin{array}{l}25.58^{* * *} \\
(8.02)\end{array}$ & $\begin{array}{l}28.29^{* * * *} \\
(8.18)\end{array}$ \\
\hline Log Offer Size & $\begin{array}{l}-5.22^{* * *} \\
(-9.19)\end{array}$ & $\begin{array}{l}-4.68^{\text {*** }} \\
(-8.18)\end{array}$ & $\begin{array}{l}-4.71^{* * *} \\
(-8.22)\end{array}$ & $\begin{array}{l}-5.38^{* * *} \\
(-9.46)\end{array}$ & $\begin{array}{l}-5.23^{* * *} \\
(-9.20)\end{array}$ & $\begin{array}{l}-7.31^{* * *} \\
(-12.39)\end{array}$ & $\begin{array}{l}-7.16^{* * *} \\
(-11.77)\end{array}$ \\
\hline Integer Offer Price & $\begin{array}{l}-1.27 \\
(-0.82)\end{array}$ & $\begin{array}{l}-1.95 \\
(-1.24)\end{array}$ & $\begin{array}{l}-0.49 \\
(-0.31)\end{array}$ & $\begin{array}{l}-3.00^{*} \\
(-1.93)\end{array}$ & $\begin{array}{l}-2.54 \\
(-1.54)\end{array}$ & $\begin{array}{l}3.24^{* *} \\
(2.09)\end{array}$ & $\begin{array}{l}-3.50^{* *} \\
(-1.96)\end{array}$ \\
\hline Book Building & $\begin{array}{l}-5.89^{* * *} \\
(-3.40)\end{array}$ & $\begin{array}{l}-4.20^{* *} \\
(-2.39)\end{array}$ & $\begin{array}{l}-2.91 \\
(-1.62)\end{array}$ & $\begin{array}{l}-4.94^{* * *} \\
(-2.69)\end{array}$ & $\begin{array}{l}-6.68^{* * *} \\
(-3.64)\end{array}$ & $\begin{array}{l}4.54^{* *} \\
(2.47)\end{array}$ & $\begin{array}{l}3.40^{*} \\
(1.74)\end{array}$ \\
\hline Equity Carve-out & $\begin{array}{l}-4.47^{* *} \\
(-2.19)\end{array}$ & $\begin{array}{l}-3.29 \\
(-1.59)\end{array}$ & $\begin{array}{l}-4.18^{*} \\
(-1.94)\end{array}$ & $\begin{array}{l}-3.96^{*} \\
(-1.88)\end{array}$ & $\begin{array}{l}-4.99^{* *} \\
(-2.45)\end{array}$ & $\begin{array}{l}2.15 \\
(0.97)\end{array}$ & $\begin{array}{l}3.67 \\
(1.59)\end{array}$ \\
\hline Underwriter Reputation & $\begin{array}{l}0.93^{* *} \\
(2.07)\end{array}$ & $\begin{array}{l}0.60 \\
(1.30)\end{array}$ & $\begin{array}{l}0.57 \\
(1.22)\end{array}$ & $\begin{array}{l}1.17^{* * *} \\
(2.66)\end{array}$ & $\begin{array}{l}0.97^{* *} \\
(2.15)\end{array}$ & $\begin{array}{l}0.67 \\
(1.50)\end{array}$ & $\begin{array}{l}0.72 \\
(1.59)\end{array}$ \\
\hline Market Return & $\begin{array}{l}0.83^{* * *} \\
(7.35)\end{array}$ & $\begin{array}{l}0.80^{* * *} \\
(6.98)\end{array}$ & $\begin{array}{l}0.84^{* * *} \\
(7.08)\end{array}$ & $\begin{array}{l}0.89^{* * *} \\
(7.44)\end{array}$ & $\begin{array}{l}0.82^{* * *} \\
(7.30)\end{array}$ & $\begin{array}{l}1.03^{* * *} \\
(8.55)\end{array}$ & $\begin{array}{l}1.14^{* * *} \\
(8.70)\end{array}$ \\
\hline IPO Hot/Cold & $\begin{array}{l}23.52^{* *} \\
(2.35)\end{array}$ & $\begin{array}{l}41.38^{* * *} \\
(4.11)\end{array}$ & $\begin{array}{l}37.28^{* * *} \\
(3.58)\end{array}$ & $\begin{array}{l}23.66^{* *} \\
(2.18)\end{array}$ & $\begin{array}{l}18.95^{*} \\
(1.86)\end{array}$ & $\begin{array}{l}45.11^{\text {*** }} \\
(4.12)\end{array}$ & $\begin{array}{l}57.20^{\text {**** }} \\
(5.02)\end{array}$ \\
\hline Stock Turnover & $\begin{array}{l}8.65^{* * *} \\
(5.30)\end{array}$ & $\begin{array}{l}5.38^{* * *} \\
(3.27)\end{array}$ & $\begin{array}{l}5.94^{* * *} \\
(3.34)\end{array}$ & $\begin{array}{l}6.26^{* * *} \\
(3.09)\end{array}$ & $\begin{array}{l}9.05^{* * *} \\
(5.43)\end{array}$ & $\begin{array}{l}-1.26 \\
(-0.63)\end{array}$ & $\begin{array}{l}-11.00^{* * *} \\
(-4.28)\end{array}$ \\
\hline Intercept & $\begin{array}{l}29.50^{* * *} \\
(-4.77)\end{array}$ & $\begin{array}{l}50.53^{* * *} \\
(7.39)\end{array}$ & $\begin{array}{l}11.22 \\
(0.84)\end{array}$ & $\begin{array}{l}34.08^{* * *} \\
(4.90)\end{array}$ & $\begin{array}{l}35.30^{* * *} \\
(5.25)\end{array}$ & $\begin{array}{l}9.44 \\
(1.64)\end{array}$ & $\begin{array}{l}14.42 \\
(0.93)\end{array}$ \\
\hline Number of obs. & 8776 & 8633 & 8527 & 8484 & 8776 & 8138 & 7674 \\
\hline Adjusted R-square & 0.0559 & 0.0656 & 0.0683 & 0.0581 & 0.0562 & 0.0770 & 0.0933 \\
\hline
\end{tabular}

Next, we further conduct following regression of IPO underpricing with all the variables of our main interests:

$$
\begin{aligned}
\mathrm{U}_{i j t}= & \alpha+\beta_{A F} * \text { Analyst Following } \\
& +\beta_{H C B} * \beta_{S P S} * \text { Stock Price Country } \text { Bias }_{j}+\beta_{\text {ASD }} * \text { Anit Self Dealing } \\
& +\beta_{P L} * \text { Prospectus Liability } \\
& +\gamma_{\text {Deal }} * \text { Deal Controls } \\
& +\gamma_{\text {Market }} * \text { Market Controls } \\
& +\delta_{t} * \text { Year Dummies }+\delta_{\text {Industry }} * \text { Industry Dummies } \\
&
\end{aligned}
$$

The result of this fully specified model is given in model M-7. Consistent with our Hypothesis 1a, in the fully specified model, the coefficient on analyst following remains negative $(-2.57)$ and significant at $1 \%$ level.

\subsubsection{Tests on outsider-outsider asymmetric information hypothesis}

We test the outsider-outsider asymmetric information hypothesis (Hypothesis 1b) in the fully specified model and following partial model with both analyst following and stock price synchronicity estimate:

$$
\begin{aligned}
\mathrm{U}_{i j t}= & \alpha+\beta_{A F} * \text { Analyst Following }_{j}+\beta_{\text {SPS }} * \text { Stock Price Synchronicity } \\
& +\gamma_{\text {Deal }} * \text { Deal Controls } \\
& +\delta_{\text {Industry }}+\gamma_{\text {Market }} * \text { Market Controls } \\
& \text { Intry Dummies }+\delta_{t} * \text { Year Dummies }+\varepsilon_{i j t} .
\end{aligned}
$$

The coefficients of stock price synchronicity in both partial model (M-3) and the fully specified model (M-7) are positive (coefficients are 0.53 in M-3 and 0.74 in M-7) and significant at 1\% level, which are consistent with the outsider-outsider asymmetric information hypothesis ( Hypothesis1b). 


\section{Table 6}

Regression results of IPO underpricing in robustness tests. This table presents the regression results of IPO underpricing in robustness tests from 2000 to 2006 . M1 presents the results in the sample excluding U.S. and Canadian IPOs. M2 presents the results in the sample excluding Asian countries (i.e., China, Hong Kong, India, Indonesia, Japan, Malaysia, Philippines, Singapore, South Korea, Taiwan, and Thailand). M3 presents the results in the sample excluding countries with smallest number of IPOs (i.e., Luxembourg, South Africa, Russia, Philippines, and India). M4 presents the results in the sample excluding countries with more than 5\% IPOs having gray market prices (i.e., Norway, Spain, Italy, Germany, Netherlands, Austria, Switzerland, Finland, Sweden, and Greece) based on Cornelli et al. (2006). M5 presents the results in the full sample for comparison purpose. IPO Underpricing is the percentage return from the offer price to the first closing price. Analyst following is the median value of firm-year analyst following estimates. Stock price synchronicity is the percentage of stocks moving in step. Home-country bias is the logarithm value of the ratio of home mutual fund investment weight in home stocks over the home stock market capitalization weight in the world market. Anti-self-dealing index represents the level of legal protection of minority shareholders against expropriation by corporate insiders. Prospectus liability index is an index of procedural difficulty in recovering losses in a civil liability case due to misleading statements in the IPO prospectus. Log offer size is the logarithm value of IPO offer size. Integer Offer Price indicates one when offer price is integer in homecountry currency. Book building indicates one when the underwriter chooses book-building as pricing technique. Equity carve-out indicates one when the issue is a carve-out deal. Underwriter reputation is the decile-reputation rank of underwriter's global market share. Market return is the cumulative local market return over last three months before the IPO issue date. IPO hot/cold is the ratio of IPO number in one year over the total IPO number during our sample period. Stock turnover is the ratio of total value of shares traded over stock market capitalization for each year and each country. t-values are reported in parentheses. ${ }^{* * *}$, ** and * stand for statistical significance based on a two-sided $t$ test at the $1 \%, 5 \%$ and $10 \%$ levels, respectively. All regressions control for year fixed effects and industry fixed effects.

\begin{tabular}{|c|c|c|c|c|c|}
\hline & M1 & M2 & M3 & M4 & M5 \\
\hline Analyst Following & $\begin{array}{l}-2.26^{* * *} \\
(-3.96)\end{array}$ & $\begin{array}{l}-5.20^{* * * *} \\
(-4.84)\end{array}$ & $\begin{array}{l}-2.54^{* * *} \\
(-5.04)\end{array}$ & $\begin{array}{l}-2.18^{* * *} \\
(-3.41)\end{array}$ & $\begin{array}{l}-2.57^{* * *} \\
(-5.09)\end{array}$ \\
\hline Stock Price Synchronicity & $\begin{array}{l}0.94^{* * *} \\
(4.25)\end{array}$ & $\begin{array}{l}-0.01 \\
(-0.03)\end{array}$ & $\begin{array}{l}0.73^{* * *} \\
(3.50)\end{array}$ & $\begin{array}{l}0.62^{* * *} \\
(2.76)\end{array}$ & $\begin{array}{l}0.74^{* * *} \\
(3.55)\end{array}$ \\
\hline Home-country Bias & $\begin{array}{l}-7.39^{* * *} \\
(-6.45)\end{array}$ & $\begin{array}{l}-4.91^{* * *} \\
(-4.42)\end{array}$ & $\begin{array}{l}-6.33^{* * *} \\
(-6.14)\end{array}$ & $\begin{array}{l}-4.31^{* * *} \\
(-3.07)\end{array}$ & $\begin{array}{l}-6.57^{* * *} \\
(-6.59)\end{array}$ \\
\hline Anti-self-dealing Index & $\begin{array}{l}-16.72^{* * *} \\
(-3.47)\end{array}$ & $\begin{array}{l}-39.81^{* * *} \\
(-4.66)\end{array}$ & $\begin{array}{l}-22.81^{\text {**** }} \\
(-5.09)\end{array}$ & $\begin{array}{l}-18.18^{* * *} \\
(-3.67)\end{array}$ & $\begin{array}{l}-21.91^{* * *} \\
(-4.99)\end{array}$ \\
\hline Prospectus Liability Index & $\begin{array}{l}19.58^{* * *} \\
(3.99)\end{array}$ & $\begin{array}{l}20.79^{* * *} \\
(5.28)\end{array}$ & $\begin{array}{l}29.70^{* * *} \\
(8.17)\end{array}$ & $\begin{array}{l}43.33^{* * *} \\
(8.95)\end{array}$ & $\begin{array}{l}28.29^{* * * *} \\
(8.18)\end{array}$ \\
\hline Log Offer Size & $\begin{array}{l}-4.69^{* * *} \\
(-6.87)\end{array}$ & $\begin{array}{l}-6.28^{* * *} \\
(-8.96)\end{array}$ & $\begin{array}{l}-7.17^{* * *} \\
(-11.72)\end{array}$ & $\begin{array}{l}-8.14^{* * *} \\
(-12.46)\end{array}$ & $\begin{array}{l}-7.16^{* * *} \\
(-11.77)\end{array}$ \\
\hline Integer Offer Price & $\begin{array}{l}2.22 \\
(1.08)\end{array}$ & $\begin{array}{l}-9.61^{* * *} \\
(-5.05)\end{array}$ & $\begin{array}{l}-3.93^{* *} \\
(-2.18)\end{array}$ & $\begin{array}{l}-1.86 \\
(-0.95)\end{array}$ & $\begin{array}{l}-3.50^{* *} \\
(-1.96)\end{array}$ \\
\hline Book Building & $\begin{array}{l}3.48 \\
(1.48)\end{array}$ & $\begin{array}{l}-6.59^{* * *} \\
(-2.84)\end{array}$ & $\begin{array}{l}3.89^{*} \\
(1.93)\end{array}$ & $\begin{array}{l}7.97^{* * *} \\
(3.69)\end{array}$ & $\begin{array}{l}3.40^{*} \\
(1.74)\end{array}$ \\
\hline Equity Carve-out & $\begin{array}{l}-2.18 \\
(-0.78)\end{array}$ & $\begin{array}{l}8.10^{* * *} \\
(3.04)\end{array}$ & $\begin{array}{l}3.46 \\
(1.47)\end{array}$ & $\begin{array}{l}1.79 \\
(0.73)\end{array}$ & $\begin{array}{l}3.67 \\
(1.59)\end{array}$ \\
\hline Underwriter Reputation & $\begin{array}{l}0.73 \\
(1.57)\end{array}$ & $\begin{array}{l}0.51 \\
(0.92)\end{array}$ & $\begin{array}{l}0.66 \\
(1.44)\end{array}$ & $\begin{array}{l}0.54 \\
(1.12)\end{array}$ & $\begin{array}{l}0.72 \\
(1.59)\end{array}$ \\
\hline Market Return & $\begin{array}{l}1.04^{* * * *} \\
(6.99)\end{array}$ & $\begin{array}{l}1.49 * * * \\
(7.95)\end{array}$ & $\begin{array}{l}1.15^{* * *} \\
(8.67)\end{array}$ & $\begin{array}{l}0.85^{* * *} \\
(6.17)\end{array}$ & $\begin{array}{l}1.14^{* * *} \\
(8.70)\end{array}$ \\
\hline IPO Hot/Cold & $\begin{array}{l}51.02^{* * *} \\
(4.22)\end{array}$ & $\begin{array}{l}42.96^{* * *} \\
(3.84)\end{array}$ & $\begin{array}{l}57.73^{* * *} \\
(4.98)\end{array}$ & $\begin{array}{l}42.45^{* *} \\
(2.18)\end{array}$ & $\begin{array}{l}57.20^{* * *} \\
(5.02)\end{array}$ \\
\hline Stock Turnover & $\begin{array}{l}-14.23^{* * *} \\
(-3.85)\end{array}$ & $\begin{array}{l}3.08 \\
(1.04)\end{array}$ & $\begin{array}{l}-11.12^{* * *} \\
(-4.31)\end{array}$ & $\begin{array}{l}-12.21^{* * *} \\
(-3.57)\end{array}$ & $\begin{array}{l}-11.00^{* * *} \\
(-4.28)\end{array}$ \\
\hline Intercept & $\begin{array}{l}-2.19 \\
(-0.12)\end{array}$ & $\begin{array}{l}85.27^{* * * *} \\
(3.48)\end{array}$ & $\begin{array}{l}14.21 \\
(0.92)\end{array}$ & $\begin{array}{l}2.23 \\
(0.12)\end{array}$ & $\begin{array}{l}14.42 \\
(0.93)\end{array}$ \\
\hline Number of obs. & 5190 & 5426 & 7628 & 6807 & 7674 \\
\hline Adjusted R-square & 0.0658 & 0.1382 & 0.0941 & 0.0867 & 0.0933 \\
\hline
\end{tabular}

In summary, consistent with our hypotheses, we find that the levels of insider-outsider information asymmetry and outsideroutsider information asymmetry are both positively associated with IPO underpricing.

\subsection{Tests on enticing costs hypothesis}

We test the enticing costs hypothesis (Hypothesis 2) implied by Stoughton and Zechner (1998) using the variable of homecountry bias, whose coefficient is expected to be negative. The fully specified model and following partial model are tested:

$$
\begin{aligned}
\mathrm{U}_{i j t}= & \alpha+\beta_{H C B} * \text { Home Country } \text { Bias }_{j}+\gamma_{\text {Deal }} * \text { Deal Controls } \\
& +\gamma_{\text {Market }} * \text { Market Controls } \\
& +\delta_{t} * \text { Year Dummies }+\varepsilon_{i j t} .
\end{aligned}
$$

The results are reported in model M-4 and M-7, in which the coefficients on home-country bias are negative ( -1.29 in $\mathrm{M}-4$ and -6.57 in M-7) and significant (significant at $10 \%$ level in M-4 and at 1\% level in M-7). These results support the Hypothesis 2 , implying that IPO underpricing can be viewed as costs to entice block holders, and investors' home-country bias helps to reduce such costs to a certain extent. 


\subsection{Tests on contract enforcement hypothesis}

To investigate the impact of the effectiveness of contract enforcement mechanisms on IPO underpricing (Hypothesis 3), we test following partial model with anti-self-dealing index as well as the fully specified model:

$$
\begin{aligned}
\mathrm{U}_{i j t}= & \alpha+\beta_{A S D} * \text { Anit Self Dealing } \\
& +\gamma_{\text {Market }} * \text { Market Controls } \\
& +\gamma_{\text {Deal }} * \text { Deal Controls } \\
& +\delta_{t} * \text { Year Dummies }+\varepsilon_{i j t} .
\end{aligned}
$$

As expected, the coefficients on anti-self-dealing index are -7.66 in the partial model M- 5 (significant at $5 \%$ level) and -21.91 in the fully specified model M-7 (significant at $1 \%$ level). These results are consistent with the contract enforcement hypothesis, i.e., IPO underpricing is lower in the countries with more effective contract enforcement mechanisms.

\subsection{Tests on litigation risk hypothesis}

To test the litigation risk hypothesis (Hypothesis 4), we examine the effect of prospectus liability index on IPO underpricing in both fully specified model and following partial model:

$$
\begin{aligned}
\mathrm{U}_{i j t}= & \alpha+\beta_{P L} * \text { Prospectus Liability } \\
& +\gamma_{\text {Market }} * \gamma_{\text {Deal }} * \text { Deal Controt Controls } \\
& +\delta_{t} * \text { Year Dummies }+\varepsilon_{i j t} .
\end{aligned}
$$

The results are consistent with our prediction. In the partial model M-6 and fully specified model M-7, coefficients on prospectus liability index are 25.58 and 28.29 respectively. Both of them are significant at $1 \%$ level. These results imply that IPO underpricing acts as a premium for insurance coverage against future litigation risk.

IPO Underpricing

IPO Underpricing is the percentage return from the offer price to the first closing price, based on Thomson Financial Securities Data Company (SDC) Platinum and DataStream databases. The earliest closing price within one week subsequent to the IPO issue date in SDC is taken firstly. If the closing price in SDC is missing, the daily closing price from DataStream within 10 days subsequent to the IPO issue date will be taken alternatively. IPO issue date and offer price are obtained from SDC.

Analyst Following Analyst Following is the median value of firm-year Analyst Following estimates in one country during the sample period from 2000 to 2006, based on I/B/E/S Summary Statistics database. Firm-year Analyst Following estimate is the number of analysts who follow one firm by issuing one-year-ahead EPS forecasts. This variable is held constant for a country in our sample period.

Stock Price Synchronicity Stock Price Synchronicity is a measure of the percentage of stocks moving in step, estimated by Morck et al. (2000). This variable is held constant for a country in our sample period.

Home-country Bias Home-Country Bias is the ratio of home mutual fund investment weight in home stocks over the home stock market capitalization weight in the world market estimated by (Lau et al., 2009). Specifically, the home--country bias measure is expressed in natural logarithm form. This variable is held constant for a country in our sample period.

Anti-self-dealing Index Anti-self-dealing index is constructed based on a questionnaire by attorneys from Lex Mundi, which is an association of international
law firms. It ranges from zero to one, with one representing the highest level of legal protection of minority shareholders against the law firms. It ranges from zero to one, with one representing the highest level of legal protection of minority shareholders against
expropriation by corporate insiders, and zero representing the lowest level of legal protection. The anti-self-dealing index data is downloaded from Professor Rafael La Porta's website. This variable is held constant for a country in our sample period.

Prospectus Liability Index Prospectus liability index is an index of procedural difficulty in recovering losses in a civil liability case due to misleading statements in the IPO prospectus reported in La Porta et al. (2006). Specifically, the liability index equals the arithmetic mean of liability standards for recovering losses from 1) issuer and its directors, 2) distributors, and 3) accountants. It varies from zero to one, with one representing the least difficulty in recovering losses, and zero representing the most difficulty. This variable is held constant for a country in our sample period.

Log Offer Size Integer Offer Price Log Offer Size is the logarithm value of IPO offer size in millions of dollars adjusted by CPI index, estimated based on SDC. Integer Offer Price is a dummy variable, which indicates one when the offer price is integer in home-country currency, estimated based on SDC.

Book Building Book Building is a dummy variable, which indicates one when the underwriter chooses book-building as pricing technique, reported in SDC.

Equity Carve-out Equity Carve-out is a dummy variable, which indicates one when the issue is a carve-out deal, reported in SDC.

Underwriter Reputation Underwriter Reputation is the decile-reputation rank of underwriter's global market share from 2000 to 2006, estimated based on SDC. If one IPO has multiple underwriters, the proceeds of this IPO will be evenly split and assigned to each underwriter's market share. The highest reputation rank of all the underwriters for each IPO is taken as the IPO-level underwriter reputation. The highest rank of underwriter reputation is ten and represents the highest decile of global IPO market share, while the lowest reputation rank is one and represents the lowest decile of market share.

Market Return Market Return is the cumulative local market return over last three month before the IPO issue date based on DataStream market index for each country.

IPO Hot/Cold IPO Hot/Cold is the ratio of IPO number in each year over the total IPO number during the period of 2000-2006 for each country, estimated based on $S D C$

Stock Turnover Stock Turnover is the ratio of total value of shares traded over stock market capitalization for each year and each country, estimated based on DataStream. 


\section{Robustness tests}

To further investigate the robustness of our results, we conduct robustness tests by excluding some of the countries from our sample. Table 6 presents our results. For example, in model M-1, we exclude both U.S. and Canadian IPOs. In model M-2, we exclude all Asian countries and in model M-3, we exclude the countries with the smallest number of IPOs during the sample period. Model M-4 presents the results in the sample excluding countries with more than $5 \%$ IPOs having gray market prices. We provide a snapshot of our full model from Table 5 as M-5 of Table 6 to facilitate comparison.

U.S. and Canada account for 2484 IPOs during our sample period, which constitute $28.28 \%$ of the IPOs in our sample. In many institutional aspects, e.g., major investment banks, analyst following, and legal recourses, U.S. and Canada are way ahead of most of the other countries in our sample. Thus, to examine whether our results are driven by matured financial markets like U.S. and Canada, we re-estimate our models after excluding U.S. and Canadian IPOs. The results are presented in model M- 1 . We find statistically significant support for all four of our hypotheses. ${ }^{30}$ In particular, we still find significant support for the litigation risk hypothesis in our multi-country analysis, although litigation risk is commonly believed to be important mainly for the U.S. market.

Next, we exclude all the Asian countries from our analysis in model M-2, to test whether regulatory differences and government influence on asset pricing account for the main results in our paper. Prior studies document regulatory impacts on IPO offer price and hence, IPO underpricing. For example, Cheung et al. (2009) document the effects of regulatory reforms during the 1992-2006 period and investigate how these regulatory changes affect IPO underpricing in China. Their study finds that the IPO pricing, based on a fixed price/earnings ratio pre-determined by the regulators, contributed significantly to the IPO underpricing in China. Similarly, Kutsuna et al. (2009) study the effects of public information on offer price formation in Japan and finds that offer prices closely reflect pre-IPO implicit agreements between underwriters and issuers that originate well before the offering. These country-level idiosyncrasies can affect out results. Hence, we re-estimate our model using the reduced sample and find all of our results hold for our non-Asian country sample, except for the stock price synchronicity. ${ }^{31}$ The coefficient on stock price synchronicity is insignificant. Thus, stock price synchronicity matters the most for Asian countries. We argue that the likelihood of potential "lemon problem," is higher in the Asian countries. This is because of inadequate private as public monitoring institutions, and lack of governments' ability and will to prosecute perpetrators of such market manipulators. Thus, a typical Asian uninformed investor worries the most about getting an allocation of overpriced IPO vis-'a-vis the fair priced (or underpriced) IPOs. Our intuition is substantiated by the fact that among the top five countries in terms of Stock Price Synchronicity ranking (China, Malaysia, Poland, South Korea, and Taiwan), four of them are Asian countries.

Further, we drop five countries with the least number of IPOs during the sample period in model M-3, to reduce the variability in number of IPOs across countries, because sometimes small number of IPO events can have large statistical impacts on price distributions without any real economic impact. These countries are India (mean of underpricing $=25.01, \mathrm{~N}=9$ ), Luxembourg (mean of underpricing $=26.68, \mathrm{~N}=15$ ), Philippines (mean of underpricing $=17.27, \mathrm{~N}=19$ ), Russia (mean of underpricing $=8.82, \mathrm{~N}=10$ ), and South Africa (mean of underpricing $=12.94, \mathrm{~N}=18$ ). In total, these countries account for $0.81 \%$ IPOs of the full sample (mean of underpricing $=17.95, \mathrm{~N}=71$ ). We find that all our results are robust and are not driven by these unrepresentative countries.

Lastly, we rebuild our sample by excluding the countries with large gray markets, and then test our hypotheses based on the new sample in model M-4. The IPO Gray Market is an over-the-counter market where dealers may execute orders for preferred customers as well as provide support for a new issue before it is actually issued. ${ }^{32}$ In such cases, IPO initial returns are lower because a market price already has been established in the gray markets. Thus, the existence of "gray market" may affect our results. Following Cornelli et al. (2006) we exclude the countries with more than 5\% IPOs with gray market prices from our sample. ${ }^{33}$ We find our results are not sensitive to exclusion/inclusion of countries with established gray market for IPOs in model $\mathrm{M}-4$.

\section{Conclusion}

Financial integration within the global economy has increased by leaps and bounds, particularly over the last two decades. However, we still know very little about how country-level characteristics affect important corporate events and common corporate behaviors. In this study, we focus on one of the most important corporate events, the initial public offering, to shed some light on the indirect cost of going public - IPO underpricing - worldwide. More specifically, we investigate how country-level characteristics, namely differences in level of information asymmetry, investors' home-country bias, effectiveness of contract enforcement mechanisms, and accessibility of legal recourse, influence IPO underpricing.

Using more than 8700 IPOs in 36 countries in the period between 2000 and 2006, we show that IPO underpricing is higher in countries with higher levels of information asymmetry, lower country bias among investors, less effective contract enforcement mechanisms, and more accessible legal recourse in place.

\footnotetext{
${ }^{30}$ We find qualitatively similar results when only excluding the U.S. IPOs.

31 These Asian countries include Australia, China, Hong Kong, India, Indonesia, Japan, New Zealand, Malaysia, Philippines, Singapore, South Korea, Taiwan, and Thailand. They account for $45.07 \%$ IPOs of the full sample (mean of underpricing $=33.93, \mathrm{~N}=3955$ ).

32 See, for example, Derrien and Kecskes (2007) for detailed discussion.

33 These countries include Austria, Finland, Germany, Greece, Italy, Netherlands, Norway, Spain, Sweden, and Switzerland. We also delete the country in Derrien and Kecskes (2007), basically only U.K., and find similar results.
} 


\section{Appendix}

Following is the list of the variable descriptions.

\section{References}

Agrawal, A., Chadha, S., Chen, M.A., 2006. Who is afraid of Reg FD? The behavior and performance of sell-side analysts following the SEC's fair disclosure rules. J. Bus. 79, 2811-2834.

Allen, F., Faulhaber, G.R., 1989. Signaling by underpricing in the IPO market. J. Financ. Econ. 23, 303-323.

Arugaslan, O., Cook, D.O., Kieschnick, R., 2004. Monitoring as motivation of IPO underpricing. J. Finance 59, $2403-2420$.

Ashbaugh-Skaife, H., Gassen, J., LaFond, R., 2006. Does Stock Price Synchronicity Represent Firm-Specific Information? The International Evidence, Unpublished Working Paper, University of Wisconsin Madison.

Beatty, R.P., Ritter, J.R., 1986. Investment banking, reputation, and the underpricing of initial public offerings. J. Financ. Econ. 15, $213-232$.

Beck, T., Demirguc-Kunt, A., Levine, R., 2000. A new database on financial development and structure. World Bank Econ.Rev. $14,597-605$.

Booth, J.R., Chua, L., 1996. Ownership dispersion, costly information, and IPO underpricing. J. Financ. Econ. 41, $291-310$.

Bradley, D.J., Jordan, B.D., Ritter, J.R., 2003. The quiet period goes out with a bang. J. Finance 58, 1-36.

Bradley, D.J., Cooney, J.W., Jordan, B.D., Singh, A.K., 2004. Negotiation and the IPO offer price: a comparison of integer vs. non-integer IPOs. J. Financ. Quant. Anal. 39, $517-540$.

Carter, R.B., Manaster, S., 1990. Initial public offerings and underwriter reputation. J. Finance 45, 1045-1067.

Carter, R.B., Dark, F.H., Singh, A.K., 1998. Underwriter reputation, initial returns, and the long-run performance of IPO stocks. J. Finance 53, $285-311$.

Chen, Q., Goldstein, I., Jiang, W., 2007. Price informativeness and investment sensitivity to stock price. Rev. Financ. Stud. 20, 619-650.

Cheung, Y., Ouyang, Z., Tan, W., 2009. How regulatory changes affect IPO underpricing in china. China Econ. Rev. 20, 692-702.

Cliff, M.T., Denis, D.J., 2004. Do initial public offering firms purchase analyst coverage with underpricing? J. Finance 59, $2871-2901$.

Cornelli, F., Goldreich, D., Ljungqvist, A.P., 2006. Investor sentiment and pre-IPO markets. J. Finance 61, 1187-1216.

Coval, J.D., Moskowitz, T.J., 1999. Home bias at home: local equity preference in domestic portfolios. J. Finance 54, $2045-2073$.

Covrig, V.M., Fontaine, P., Jimenez-Garces, S., Seasholes, M.S., 2008. Information Asymmetries, Common Factors, and International Portfolio Choice, Unpublished Working Paper. California State University, Northridge.

Dasgupta, S., Gan, J., Gao, N., 2010. Transparency, price informativeness, stock return synchronicity: theory and evidence. J. Financ. Quant. Anal. 45, 1189-1220. Derrien, F., Kecskes, A., 2007. The initial public offerings of listed firms. J. Finance 62, 447-479.

Djankov, S., La Porta, R., Lopez-De-Silanes, F., Shleifer, A., 2008. The law and economics of self-dealing. J. Financ. Econ. 88, 430-465.

Durnev, A., Morck, R., Yeung, B., Zarowin, P., 2003. Does greater firm-specific return variation mean more or less informed stock pricing? J. Account. Res. 41, 797-836.

Durnev, A., Morck, R., Yeung, B., 2004. Value enhancing capital budgeting and firm-specific stock return variation. J. Finance 59, 65-105.

Fama, E.F., French, K.R., 1997. Industry costs of equity. J. Financ. Econ. 43, 153-193.

Grinblatt, M., Hwang, C.Y., 1989. Signalling and the pricing of new issues. J. Finance 44, 393-420.

Habib, M.A., Ljungqvist, A.P., 1998. Underpricing and IPO proceeds: a note. Econ. Lett. 61, 381-383.

Henderson, B.J., Jegadeesh, N., Weisbach, M.S., 2006. World markets for raising new capital. J. Financ. Econ. 82, 63-101.

Hope, O.K., 2003. Disclosure practices, enforcement of accounting standards, and analysts' forecast accuracy: an international study. J. Account. Res. 41, $235-272$. Hopp, A., Dreher, C., 2010. Do differences in institutional and legal environments explain cross-country variation in IPO underpricing? J. Bank. Finance. Forthcom. Hughes, P.J., Thakor, A.V., 1992. Litigation risk, intermediation, and the underpricing of initial public offerings. Rev. Financ. Stud. 5, 709-742.

Hutton, A.P., 2005. Determinants of managerial earnings guidance prior to regulation fair disclosure and bias in analysts' earnings forecasts. Contemp. Account. Res. $22,867-914$

Ibbotson, R.G., 1975. Price performance of common stock new issues. J. Financ. Econ. 3, 235-272.

Kim, W., Weisbach, M.S., 2008. Motivations for public equity offers: an international perspective. J. Financ. Econ. 87, $281-307$.

Kutsuna, K., Smith, J.K., Smith, R.L., 2009. Public information, IPO price formation, and long-run returns: Japanese evidence. J. Finance 64, $505-546$.

La Porta, R., Lopez-De-Silanes, F., Shleifer, A., 2006. What works in securities laws? J. Finance 61, 1-32.

Lau, S.T., Ng, L., Zhang, B., 2009. The World Price of Home Bias. Journal of Financial EconomicsForthcoming.

Ljungqvist, A.P., 2007. IPO Underpricing. Handbook of Corporate Finance, North-Holland, Amsterdam.

Ljungqvist, A.P., Wilhelm, W.J., 2002. IPO allocations: discriminatory or discretionary. J. Financ. Econ. 65, $167-201$.

Ljungqvist, A.P., Jenkinson, T., Wilhelm, W.J., 2003. Global integration in primary equity markets: the role of U.S. banks and U.S. investors. Rev. Financ. Stud. 16, 63-99.

Ljungqvist, A.P., Nanda, V., Singh, R., 2006. Hot markets, investor sentiment, and IPO pricing. J. Bus. 79, 1667-1702.

Loughran, T., Ritter, J.R., 2004. Why has IPO underpricing changed over time? Financ. Manage. 33, 5-37.

Loughran, T., Ritter, J.R., Rydqvist, K., 1994. Initial public offering: international insights. Pacific-Basin Finance J. 2, $165-199$.

Lowry, M., Shu, S., 2002. Litigation risk and IPO underpricing. J. Financ. Econ. 65, 309-335.

Megginson, W.L., Weiss, K.A., 1991. Venture capitalist certification in initial public offerings. J. Finance 46, 879-903.

Michaely, R., Shaw, W.H., 1994. The pricing of initial public offerings: tests of adverse-selection and signaling theories. Rev. Financ. Stud. 7, 279-319.

Morck, R., Yeung, B., Yu, W., 2000. The information content of stock markets: why do emerging markets have synchronous stock price movements? J. Financ. Econ. $58,215-260$

Prezas, A.P., Tarimcilar, M., Vasudeva, G.K., 2000. The pricing of equity carve-outs. Financ. Rev. 35, 123-138.

Ravid, S.A., Spiegel, M., 1997. Optimal financial contracts for a start-up with unlimited operating discretion. J. Financ. Quant. Anal. 32, 269-286.

Ritter, J.R., 1984. The hot issue market of 1980. J. Bus. 57, 215-240.

Ritter, J.R., 2003. Investment Banking and Securities Issuance. Handbook of the Economics of Finance, North-Holland, Amsterdam.

Ritter, J.R., Welch, I., 2002. A review of IPO activity, pricing and allocations. J. Finance 57, 1795-1828.

Ritter, J.R., Zhang, D., 2007. Affiliated mutual funds and the allocation of initial public offerings. J. Financ. Econ. 86, 337-368.

Rock, K., 1986. Why new issues are underpriced. J. Financ. Econ. 15, 187-212.

Sherman, A.E., 2005. Global trends in IPO methods: book building versus auctions with endogenous entry. J. Financ. Econ. 78, 615-649.

Smart, S.B., Zutter, C.J., 2003. Control as a motivation for underpricing: a comparison of dual and single-class IPOs. J. Financ. Econ. 69, 85-110.

Stoll, H.R., 1989. Inferring the components of the bid-ask spread: theory and empirical tests. J. Finance 44, 114-134.

Stoll, H.R., Curley, A.J., 1970. Small business and the new issues market for equities. J. Financ. Quant. Anal. 5, 309-322.

Stoughton, N.M., Zechner, J., 1998. IPO mechanisms, monitoring and ownership structure. J. Financ. Econ. 49, $45-77$.

Tinic, S.M., 1988. Anatomy of initial public offerings of common stock. J. Finance 43, 789-822.

Welch, I., 1989. Seasoned offerings, imitation costs, and the underpricing of initial public offerings. J. Finance 44, 421-449. 